\title{
A Highly Efficient Environmental-Friendly Adsorbent Based on Schiff Base for Removal of Cu(II) from Aqueous Solutions: A Combined Experimental and Theoretical Study
}

\author{
Said Tighadouini ${ }^{1, *}$, Othmane Roby ${ }^{1}$, Smaail Radi ${ }^{2, *} \mathbb{C}$, Zouhair Lakbaibi $^{3}{ }^{\mathbb{D}}$, Rafik Saddik ${ }^{1}$, \\ Yahia N. Mabkhot ${ }^{4, *(D)}$, Zainab M. Almarhoon ${ }^{5}$ (D) and Yann Garcia ${ }^{6, *(D)}$ \\ 1 Laboratory of Organic Synthesis, Extraction and Valorization, Faculty of Sciences Ain Chock, Hassan II \\ University, BP 5366, Casablanca 20000, Morocco; othmaneroby1@gmail.com (O.R.); \\ rafik.saddik@gmail.com (R.S.) \\ 2 LCAE, Faculty of Sciences, University Mohamed Premier, Oujda 60000, Morocco \\ 3 Laboratory of Molecular Chemistry, Materials and Environment (LCME2), Multidisciplinary Faculty Nador, \\ University Mohamed Premier, Oujda, BP 300 Selouane, Nador 62700, Morocco; lakbaibi.zouhair@gmail.com \\ 4 Department of Pharmaceutical Chemistry, College of Pharmacy, King Khalid University, P.O. Box 960, \\ Abha 61421, Saudi Arabia \\ 5 Department of Chemistry, College of Science, King Saud University, P.O. Box 2455, \\ Riyadh 11451, Saudi Arabia; zalmarhoon@ksu.edu.sa \\ check for \\ updates \\ Citation: Tighadouini, S.; Roby, O.; \\ Radi, S.; Lakbaibi, Z.; Saddik, R.; \\ Mabkhot, Y.N.; Almarhoon, Z.M.; \\ 6 Institute of Condensed Matter and Nanosciences, Molecular Chemistry, Materials and \\ Catalysis (IMCN/MOST), Université Catholique de Louvain, Place Louis Pasteur 1, \\ 1348 Louvain-la-Neuve, Belgium \\ * Correspondence: tighadouinis@gmail.com (S.T.); s.radi@ump.ac.ma (S.R.); ygaber@kku.edu.sa (Y.N.M.); \\ yann.garcia@uclouvain.be (Y.G.)
} Garcia, Y. A Highly Efficient Environmental-Friendly Adsorbent Based on Schiff Base for Removal of $\mathrm{Cu}$ (II) from Aqueous Solutions: A Combined Experimental and Theoretical Study. Molecules 2021, 26 , 5164. https://doi.org/10.3390/ molecules 26175164

Academic Editors: Elza Bontempi, Margarida Quina and Anna Bogush

Received: 27 July 2021

Accepted: 21 August 2021

Published: 26 August 2021

Publisher's Note: MDPI stays neutral with regard to jurisdictional claims in published maps and institutional affiliations.

Copyright: () 2021 by the authors. Licensee MDPI, Basel, Switzerland. This article is an open access article distributed under the terms and conditions of the Creative Commons Attribution (CC BY) license (https:// creativecommons.org/licenses/by/ $4.0 /)$.

\begin{abstract}
Removal of heavy metals from drinking water sources and rivers is of strategic health importance and is essential for sustainable ecosystem development, in particular in polluted areas around the globe. In this work, new hybrid inorganic-organic material adsorbents made of ortho(Si-o-OR) or para-Schiff base silica (Si-p-OR) were synthesized and characterized in depth. These hybrid adsorbents show a high selectivity to $\mathrm{Cu}(\mathrm{II})$, even in the presence of competing heavy metals ( $\mathrm{Zn}(\mathrm{II}), \mathrm{Cd}(\mathrm{II})$, and $\mathrm{Pb}(\mathrm{II})$ ), and also demonstrate great reusability after five adsorption-desorption cycles. Maximum sorption capacity for $\mathrm{Cu}$ (II) was found for Si-o-OR $\left(79.36 \mathrm{mg} \mathrm{g}^{-1}\right)$ and Si-p-OR $\left(36.20 \mathrm{mg} \mathrm{g}^{-1}\right)$ in no less than $25 \mathrm{~min}$. Energy dispersive $\mathrm{X}$-ray fluorescence and Fourier transforminfrared spectroscopy studies demonstrate that this uptake occurs due to a chelating effect, which allows these adsorbents to trap $\mathrm{Cu}$ (II) ions on their surfaces; this result is supported by a theoretical study for Si-o-OR. The new adsorbents were tested against real water samples extracted from two rivers from the Oriental region of Morocco.
\end{abstract}

Keywords: heavy metal pollution; environment; hybrid materials; water cleaning technologies; DFT

\section{Introduction}

In recent years, industrial sites contaminated by heavy metals have contributed to growing pollution of the overall ecosystem [1]. Heavy metals are not biodegradable, and therefore tend to accumulate and remain in water bodies for a long time. This leads to long-term detrimental effects to the ecosystem and human health in general. Ref. [2] Amongst these toxic metals, $\mathrm{Cu}(\mathrm{II})$ ions, as well as others, accumulate in the body even when present at quite a low concentration, resulting in health problems and leading to an irritation of the central nervous system, stomach discomfort, decreased kidney function, mucosal irritation and even development of Alzheimer's disease, to name but a few [3].

A suitable method is thus needed for removing and selectively recovering $\mathrm{Cu}$ (II) from drinkable water. Currently, several remediation approaches and techniques have been 
applied to capture $\mathrm{Cu}(\mathrm{II})$ ions, such as ion exchange [4], coagulation [5], liquid-phase extraction [6], membrane separation [7], electrodeposition [8] and reverse osmosis [9].

Adsorption is actually considered a privileged method due to its economic simplicity, environmental friendliness and low energy requirements [10]. However, the first adsorbents were found to display low removal efficiency as well as low regeneration capability; furthermore, they do not possess selective adsorption capacity in the presence of a mixture of metal ions [11]. Recent research has focused on mesoporous silica due to its high specific surface area, absence of swelling, and fast kinetics, as well as their thermal, mechanical stabilities and compatibilities with other materials [12-14]. Recently, chemical engineering of organically modified porous silica has attracted attention for the adsorption of metal ions in environmental remediation [15-19]. Their adsorption performances mainly depend on donor atoms within the incorporated organic moieties, which can form chelating structures with metal ions, e.g., Schiff bases with $\mathrm{Cu}$ (II) [20-24].

Schiff base-functionalized siloxanes have been discovered as promising candidates for decreasing toxic metal concentrations in water $[25,26]$. On the other hand, these materials and their complexes have also generated an interest in homogeneous catalysis $[27,28]$.

In the present work, we have designed new adsorbents via the covalent immobilization of two furan derivatives on silica particles, namely Si-o-OR and Si-p-OR. The effect of contact time, $\mathrm{pH}$, initial metal ion concentration temperature, recyclability, and coexisting metal ions on the adsorption of $\mathrm{Cu}(\mathrm{II}), \mathrm{Zn}(\mathrm{II}), \mathrm{Cd}(\mathrm{II})$ and $\mathrm{Pb}(\mathrm{II})$ was explored. The adsorption mechanism was investigated through FTIR spectroscopy and computational means. A strong coordination of $\mathrm{Cu}$ (II) in a monodentate chelating fashion with a nitrogen atom of the azomethine group of the two studied Schiff bases was evidenced, with superior characteristics demonstrated by Si-o-OR. The selected adsorbent was used to successfully remove $\mathrm{Cu}$ (II) from aqueous solutions, including real river water samples, with a high maximum sorption capacity of $79.36 \mathrm{mg} \mathrm{g}^{-1}$.

\section{Results}

\subsection{Linker Synthesis}

The synthesis route of the new hybrid materials is outlined in Scheme 1.

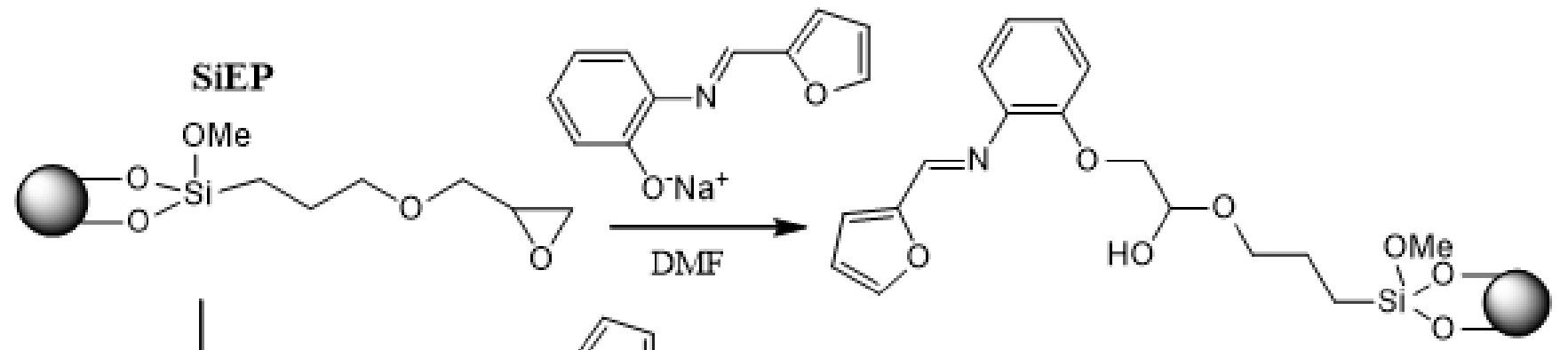<smiles>CC(C)(N)[18O]c1ccc(/N=C/c2ccco2)cc1</smiles>

\section{Si-0-OR}<smiles>CO[Si]1(CCCOCC(O)COc2ccc(/N=C/c3ccco3)cc2)Oc2cccc(c2)O1</smiles>

\section{Si-p-OR}

Scheme 1. Synthesis route of Si-p-OR and Si-o-OR.

The first stage concerns the target ligands, (E)-4-(furan-2-ylmethyleneamino) phenol or (E)-2-(furan-2-ylmethyleneamino) phenol. The next step involves condensation of activated 
silica gel with 3-glycidoxypropyltrimethoxysilane in refluxing toluene, which afforded epoxy groups on the silica surface SiEp. Finally, the epoxy groups grafted on the silica surface were then reacted to yield new hybrid materials named ortho-Schiff base silica Si-o-OR and para-Schiff base silica Si-p-OR.

\subsection{Characterization of Si-p-OR and Si-o-OR}

Chemical analysis was as shown herein in (\%): C, 6.38; H, 1.32; and N, 1.04 for Si-oOR; and C, 5.84; H, 1.34; and N, 1.13 for Si-p-OR. This allowed for the confirmation of the successful syntheses of both materials.

The FTIR spectra of SiG, Si-EP, Si-o-OR and Si-p-OR are shown in Figure 1. For SiEp, the stretching vibration at $798 \mathrm{~cm}^{-1}$ and $1097 \mathrm{~cm}^{-1}$ correspond to $\mathrm{Si}-\mathrm{O}-\mathrm{Si}$, and the weak band at $2883 \mathrm{~cm}^{-1}$ is due to the $\mathrm{CH}$ bond. In the spectra of Si-o-OR and Si-p-OR, a new peak appeared at $1460 \mathrm{~cm}^{-1}$ and $1463 \mathrm{~cm}^{-1}$, which was attributed to the characteristic $C=N$ bending vibration. These results indicate that these materials were modified by Schiff base functional groups.

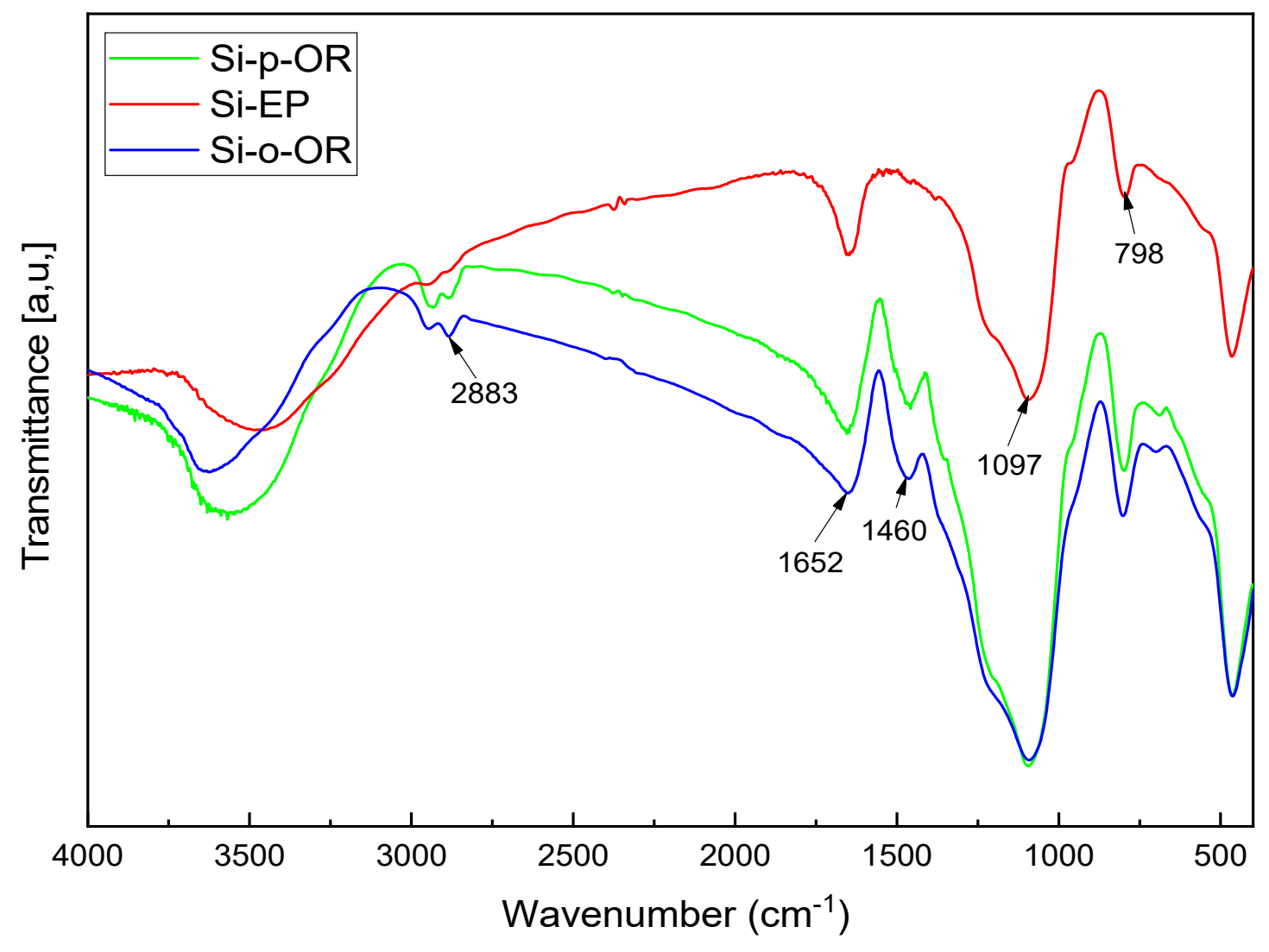

Figure 1. FTIR spectra of Si-EP, Si-o-OR and Si-p-OR.

The surface morphologies of Si-o-OR and Si-p-OR were observed by scanning electron micrographs (SEM). As displayed in Figure 2, both materials present similar rough surfaces, with a wide distribution of particle micrometer-measured size. In contrast, both materials were better dispersed than SiEP. The results confirm the successful introduction of Schiff base ligands over SiEP. 


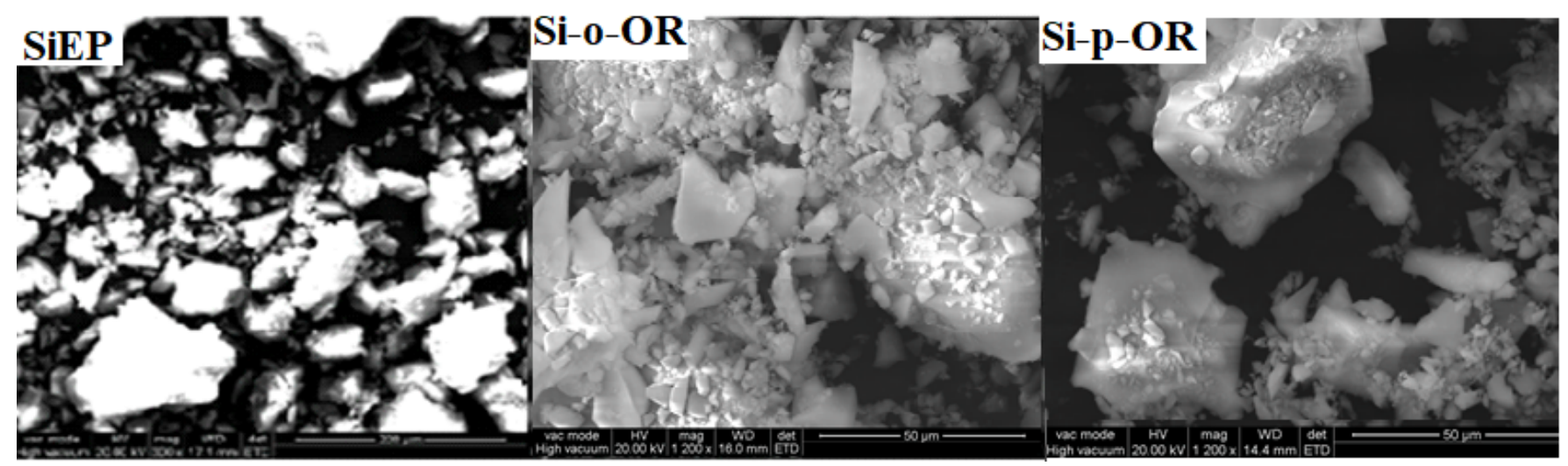

Figure 2. SEM images of Si-EP, Si-o-OR and Si-p-OR materials.

Thermogravimetric analyses of SiEP, Si-o-OR and Si-p-OR were undertaken (Figure 3). SiEP show a mass loss of $10.8 \%$ between 200 and $800{ }^{\circ} \mathrm{C}$, which corresponds to the decomposition of the silanol groups bound to the surface. For Si-o-OR and Si-p-OR, two decomposition steps are observed. The first one presents a weight loss of $3.98 \%$ for Sip-OR and $4.25 \%$ for Si-o-OR, which starts in the range of $25-100{ }^{\circ} \mathrm{C}$ and which mainly corresponds to water loss. The second step shows a mass loss of $12.91 \%$ and $13.42 \%$ for the two hybrid materials, respectively, which can be ascribed to the decomposition of the (furan-2-ylmethyleneamino) phenol ligand.

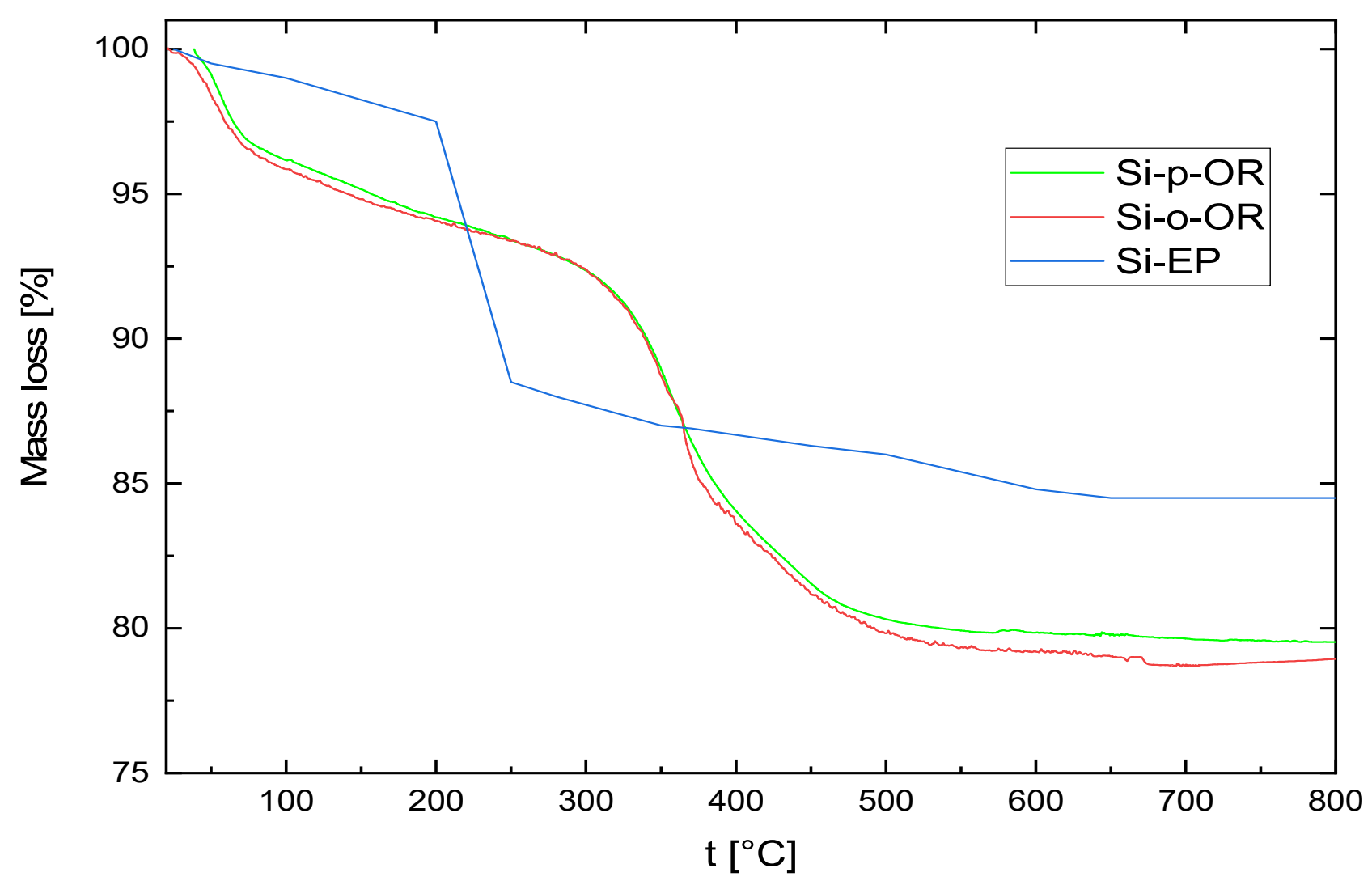

Figure 3. Thermogravimetric profiles of Si-EP, Si-o-OR and Si-p-OR.

The $\mathrm{N}_{2}$ adsorption-desorption isotherms and the corresponding BJH pore size distribution of SiEP, Si-o-OR and Si-p-OR were investigated. Figure 4 shows a type IV isotherm with a visible hysteresis loop, indicating an H2-type profile (IUPAC) and a uniform pore diameter distribution in the mesoporous region [29]. The BET surface area, total 
pore volume and pore size are $245.06 \mathrm{~m}^{2} \mathrm{~g}^{-1}, 0.65 \mathrm{~cm}^{3} \mathrm{~g}^{-1}$ and $62.75 \AA$, for Si-o-OR and $252.12 \mathrm{~m}^{2} \mathrm{~g}^{-1}, 0.66 \mathrm{~cm}^{3} \mathrm{~g}^{-1}$ and $64.09 \AA$, for Si-p-OR, respectively. This is as compared to SiEP, which demonstrates a pronounced decrease in BET surface area $\left(277.08 \mathrm{~m}^{2} \mathrm{~g}^{-1}\right)$, pore volume $\left(0.68 \mathrm{~cm}^{3} \mathrm{~g}^{-1}\right)$ and pore size $(79.6 \AA)$. These results suggest that the large surface of products was efficiently imprinted.

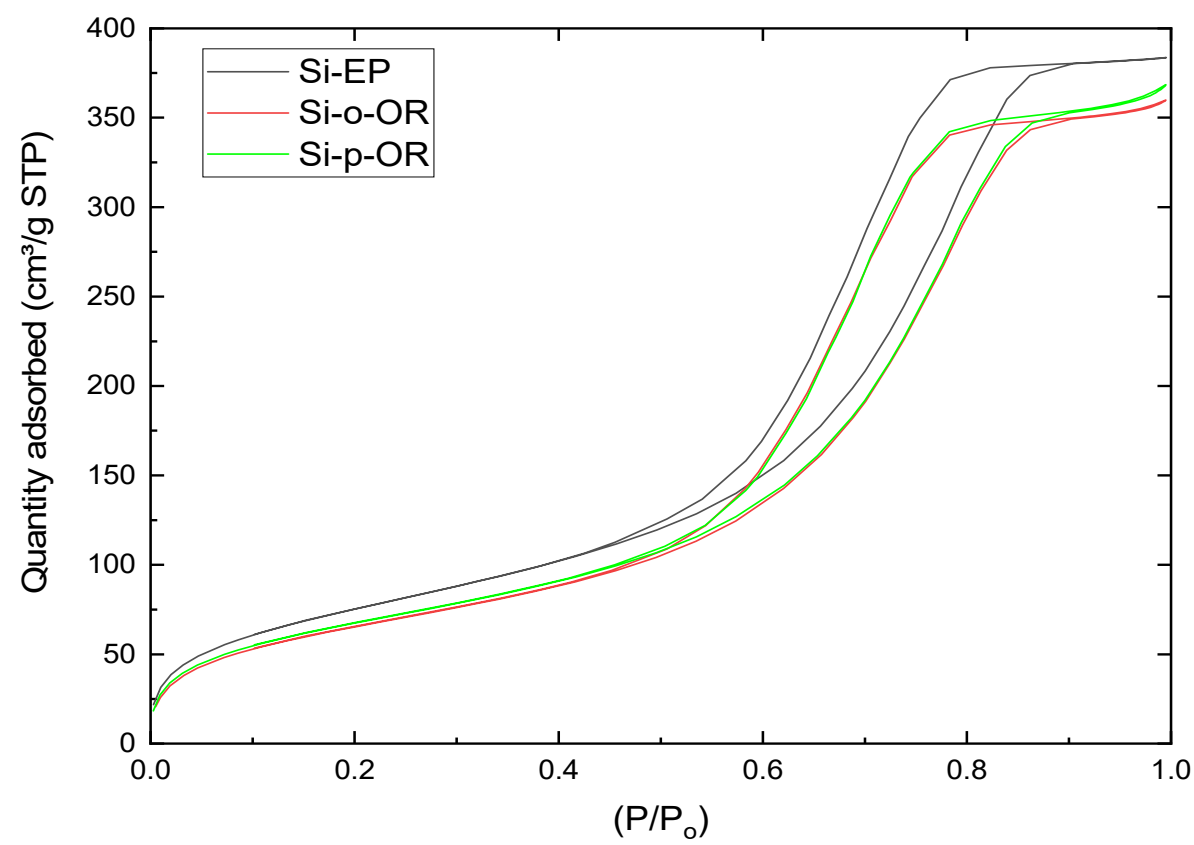

Figure 4. Nitrogen adsorption-desorption isotherm plots of Si-Ep, Si-o-OR and Si-p-OR.

\subsection{Adsorption Studies}

\subsubsection{Effect of $\mathrm{pH}$ on the Adsorption of $\mathrm{Cu}$ (II)}

$\mathrm{pH}$ is a key factor to consider during the adsorption process. The influence of $\mathrm{pH}$ ranging from 1-7 on the adsorption of $\mathrm{Cu}(\mathrm{II})$ in both adsorbents is illustrated in Figure 5 , which demonstrates that the uptake capacity of $\mathrm{Cu}(\mathrm{II})$ increased to its maximum value at $\mathrm{pH}=6$. This behaviour can be explained by the surface charge of the adsorbents with varying $\mathrm{pH}$ in an aqueous solution. The Schiff base and oxygen-containing functional groups on the surface of the materials are responsible for strong interactions with $\mathrm{Cu}(\mathrm{II})$ and have a high adsorption capacity on $\mathrm{Cu}(\mathrm{II})$. Comparing the results of Si-o-OR alone with Sip-OR at different $\mathrm{pH}$ values demonstrates a high increase in the removal of $\mathrm{Cu}$ (II) (79.36 and $36.20 \mathrm{mg} \mathrm{g}^{-1}$, respectively), which suggests that the availability of the functional groups of Si-o-OR is higher than for Si-p-OR. Si-o-OR therefore features a high coordinating capacity for $\mathrm{Cu}(\mathrm{II})$.

At $\mathrm{pH}<2$, the adsorption capacity is low. Since the active groups of both Si-o-OR and Si-p-OR are easily protonated, $\mathrm{N}$ and $\mathrm{O}$ atoms' electron-donating ability is weakened. At $\mathrm{pH}>7$, the abilities of Si-o-OR and Si-p-OR decrease due to $\mathrm{Cu}(\mathrm{OH})_{2}$ and $\mathrm{CuOH}^{+}$ formation. Overall, $\mathrm{pH}=6$ was chosen as the best condition for $\mathrm{Cu}$ (II) in subsequent experiments. Thus, Schiff base and oxygen-containing functional groups are good chelating agents that allow more copper ions to be adsorbed.

In addition to the $\mathrm{pH}$ value, the point of zero charges $\left(\mathrm{pH}_{\mathrm{PZC}}\right)$ is one of the key parameters in studying the surface charge of the adsorbents. The $\mathrm{pH}_{\mathrm{PZC}}$ of adsorbents was determined by solid addition as described in the literature [30]. Briefly, $0.01 \mathrm{~g}$ of Si-o-OR and Si-p-OR were mixed with aliquots of $30 \mathrm{~mL}$ of $\mathrm{NaOH}(0.1 \mathrm{M})$, which were prepared at different a range of different $\mathrm{pH}$ values (2-8) by using $\mathrm{HCl}(0.1 \mathrm{M})$ and $\mathrm{NaOH}(0.1 \mathrm{M})$ to fine-tune the $\mathrm{pH}$ of the solution. The point at which $\Delta \mathrm{pH}=0\left(\Delta \mathrm{pH}=\mathrm{pH}_{\text {final }}-\mathrm{pH}_{\text {initial }}\right)$ indicates $\mathrm{pH}_{\mathrm{PZC}}$ of both adsorbents. The $\mathrm{pH}_{\mathrm{PZC}}$ of $\mathbf{S i - o - O R}$ and $\mathbf{S i - p - O R}$ were found to be at 5.5 and 5, respectively (Figure 6). At $\mathrm{pH}<\mathrm{pH}_{\mathrm{PZC}}$, the $\mathrm{N}$ and $\mathrm{O}$ donor atoms remain in 
their protonated form, which results in the adsorbents bearing a positive surface charge. Higher $\mathrm{pH}$ values compared to $\mathrm{pH}_{\mathrm{PZC}}$ indicates that the surface of the adsorbent becomes negatively charged, corresponding to deprotonation of the donor atoms.

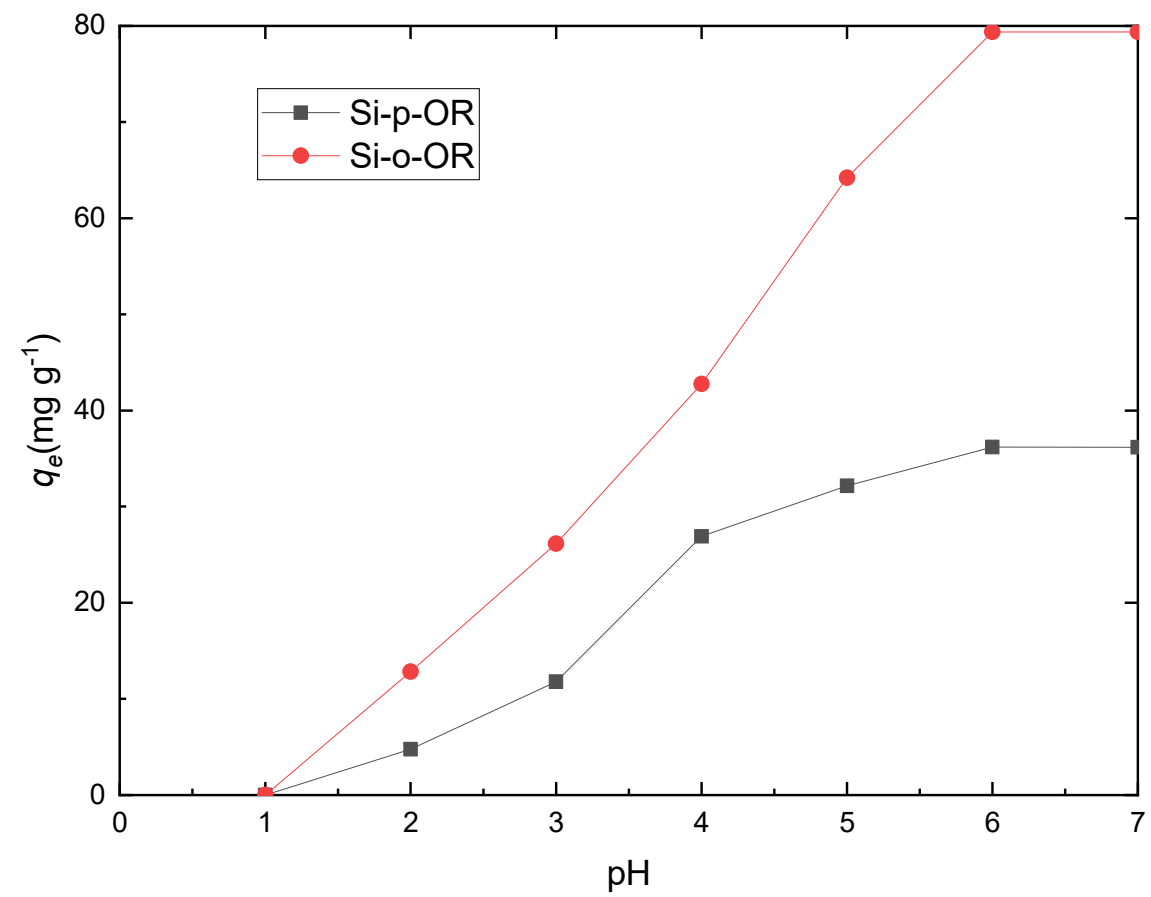

Figure 5. The effect of $\mathrm{pH}$ on the adsorption capacity of Si-o-OR and Si-p-OR towards $\mathrm{Cu}(\mathrm{II})$. Adsorption condition: $\mathrm{V}=10 \mathrm{~mL}, \mathrm{~m}=10 \mathrm{mg}$ of adsorbent and optimum concentration $=120 \mathrm{mg} \mathrm{L}^{-1}$ for $25 \mathrm{~min}$ at $25^{\circ} \mathrm{C}$.

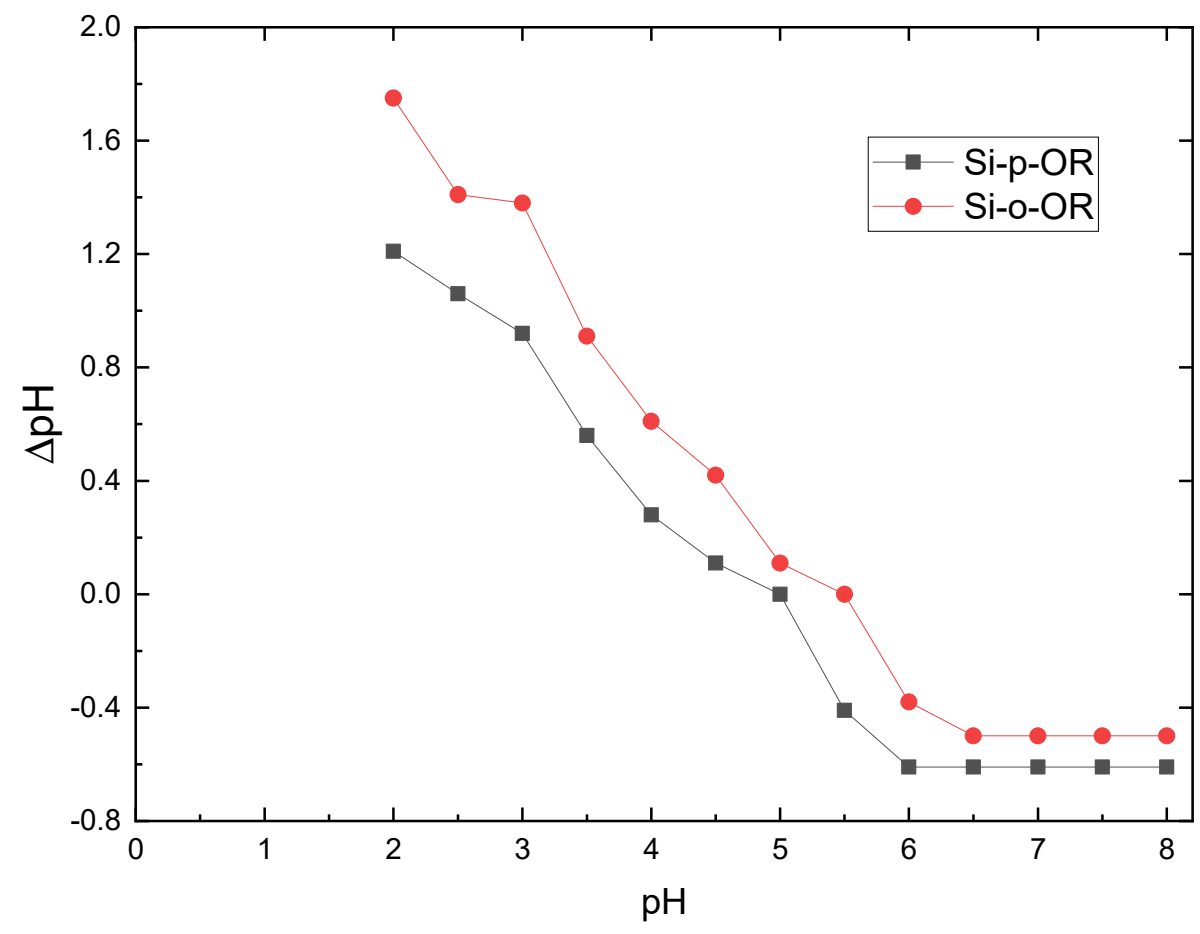

Figure 6. $\mathrm{pH}_{\mathrm{PZC}}$ determination of Si-o-OR and Si-p-OR at different $\mathrm{pH}$ values. Adsorption condition: $\mathrm{V}=10 \mathrm{~mL}, \mathrm{~m}=10 \mathrm{mg}$ of adsorbent and optimum concentration $=120 \mathrm{mg} \mathrm{L}^{-1}$ for $25 \mathrm{~min}$ at $25^{\circ} \mathrm{C}$. 


\subsubsection{Effect of Contact Time and Kinetic Adsorption Modelling}

Contact time is known to have a great influence on the adsorption efficiency of heavy metals in aqueous solutions. Adsorption time was investigated over the range of 5-35 min. The contact effect on the adsorption behaviours of Si-o-OR and Si-p-OR beads is shown in Figure 7. The removal of $\mathrm{Cu}$ (II) is rapid due to a large number of donor atoms which rapidly react with copper when the adsorbent is initially exposed to the copper solution. Evidently, over $95 \%$ adsorption occurred within $15 \mathrm{~min}$, and equilibrium was reached after $25 \mathrm{~min}$. Subsequently, no significant change occurred with time up to $40 \mathrm{~min}$, since numerous active sites on the surface of the adsorbents were consumed. Therefore, in further experiments, $25 \mathrm{~min}$ was selected to ensure the saturation of $\mathrm{Cu}$ (II) ions.

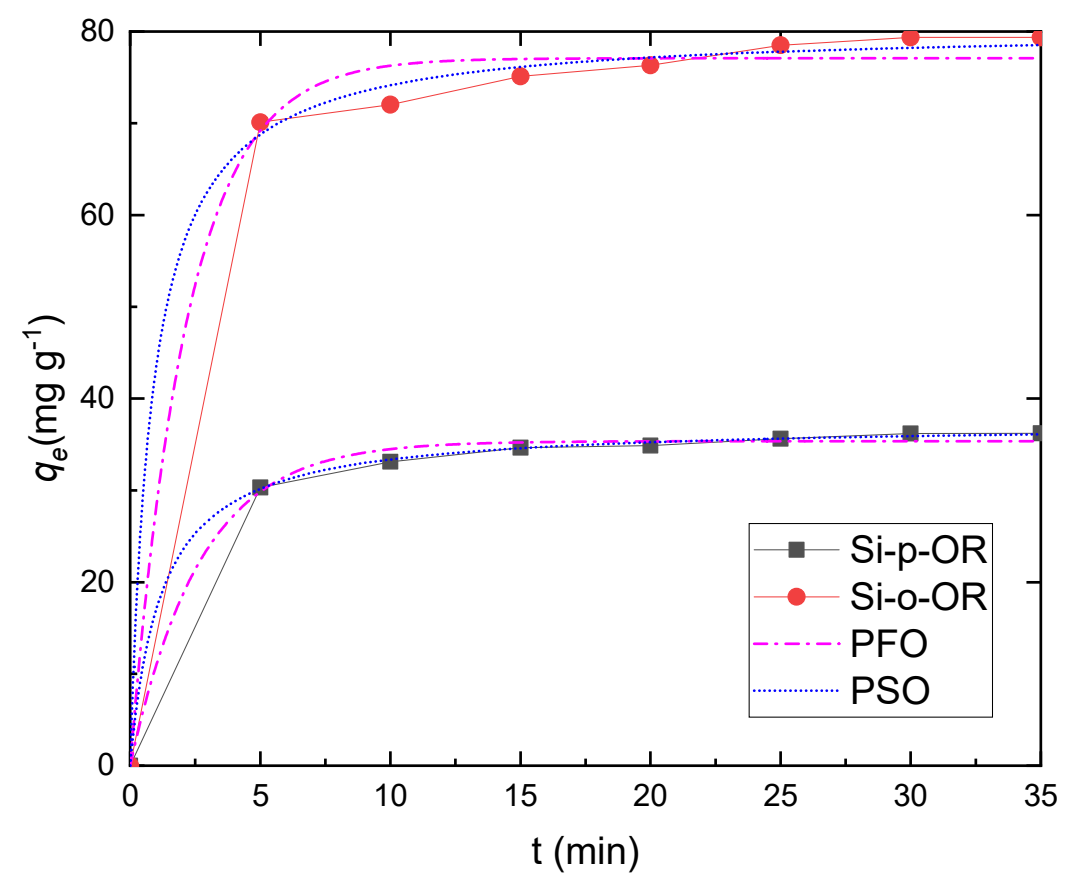

Figure 7. Adsorption of $\mathrm{Cu}(\mathrm{II})$ by Si-o-OR and Si-p-OR with time, fitted by a pseudo-secondorder model. Adsorption conditions: $\mathrm{V}=10 \mathrm{~mL}, \mathrm{~m}=10 \mathrm{mg}$ of adsorbent, $\mathrm{pH}=6$, and optimum concentration $=120 \mathrm{mg} \mathrm{L}^{-1}$ at $25^{\circ} \mathrm{C}$.

Pseudo-first-order and pseudo-second-order kinetic models were employed to analyse the adsorption kinetic data. The non-linear form of the two models can be described by Equations (4) and (5) [31,32].

Pseudo-first-order model:

$$
\mathrm{q}_{\mathrm{t}}=\mathrm{q}_{\mathrm{e}}\left[1-\mathrm{e}^{\left.-\mathrm{k}_{1} \mathrm{t}\right]}\right.
$$

Pseudo-second-order model:

$$
q_{t}=k^{2} q_{e}{ }^{2} t / 1+k_{2} q_{2} t
$$

where $\mathrm{q}_{\mathrm{e}}(\mathrm{mg} / \mathrm{g})$ and $\mathrm{q}_{\mathrm{t}}(\mathrm{mg} / \mathrm{g})$ are the amount of $\mathrm{Cu}(\mathrm{II})$ adsorbed at equilibrium and instantaneous time $\mathrm{t}$ respectively; $\mathrm{k}_{1}\left(\mathrm{~min}^{-1}\right)$ and $\mathrm{k}_{2}\left(\mathrm{~g} / \mathrm{mg} \mathrm{min}^{-1}\right)$ are the rate constants of the pseudo-first-order and pseudo-second-order expressions, respectively.

Fit results are gathered in Table 1 along with kinetic constants and correlation coefficients $\left(R^{2}\right)$. The $R^{2}$ values of the pseudo-second-order model were found to be higher than the values of the pseudo-first-order model. The theoretical value $\mathrm{q}_{\mathrm{e}}$ from the pseudosecond-order model best fitted the experimental values, which suggests that such a model is recommended to describe the adsorption kinetics of $\mathrm{Cu}(\mathrm{II})$ ion for both adsorbents. Therefore, chemisorption is the main factor in the rate of adsorption and involves complexation sharing between the adsorbent and the metal ions. 
Table 1. Kinetics model data of $\mathrm{Cu}(\mathrm{II})$ adsorption.

\begin{tabular}{cccc}
\hline \multirow{2}{*}{ Models } & Parameters & \multicolumn{2}{c}{ Adsorbents } \\
\cline { 3 - 4 } & & Si-o-OR & Si-p-OR \\
\hline \multirow{3}{*}{ Pseudo-first-order } & $\mathrm{q}_{\exp }\left(\mathrm{mg} \mathrm{g}^{-1}\right)$ & 79.36 & 36.20 \\
& $\mathrm{qe}_{\mathrm{e}}\left(\mathrm{mg} \mathrm{g}^{-1}\right)$ & 76.00 & 34.00 \\
Pseudo-second-order & $\mathrm{k}_{1}\left(\mathrm{~min}^{-1}\right)$ & 0.45 & 0.36 \\
& $\mathrm{R}^{2}$ & 0.993 & 0.996 \\
& $\mathrm{q}_{2}\left(\mathrm{~g} \mathrm{mg} \mathrm{g}^{-1}\right)$ & 80.00 & 36.00 \\
& $\left.\mathrm{Kmin}^{-1}\right)$ & 0.01 & 0.02 \\
& & 0.997 & 0.999 \\
\hline
\end{tabular}

\subsubsection{Influence of Initial Concentration and Adsorption Isotherms for $\mathrm{Cu}(\mathrm{II})$}

The initial concentration is one of the most important factors that provide necessary information about adsorbing performance in different concentrations. Accordingly, different initial concentrations of $\mathrm{Cu}$ (II) ranging from 10 to $300 \mathrm{mg} \mathrm{L}^{-1}$ were used to study the adsorbents further using the batch method. The effect of the initial concentration on the adsorption capacity of $\mathrm{Cu}(\mathrm{II})$ is illustrated in Figure 8. It can be seen that the removal of $\mathrm{Cu}$ (II) ion increases with an increase in $\mathrm{Cu}$ (II) ion concentration. This is attributed to the higher driving force arising from the high concentration gradient. The adsorption curve tends to reach a plateau corresponding to the saturated sorption monolayer.

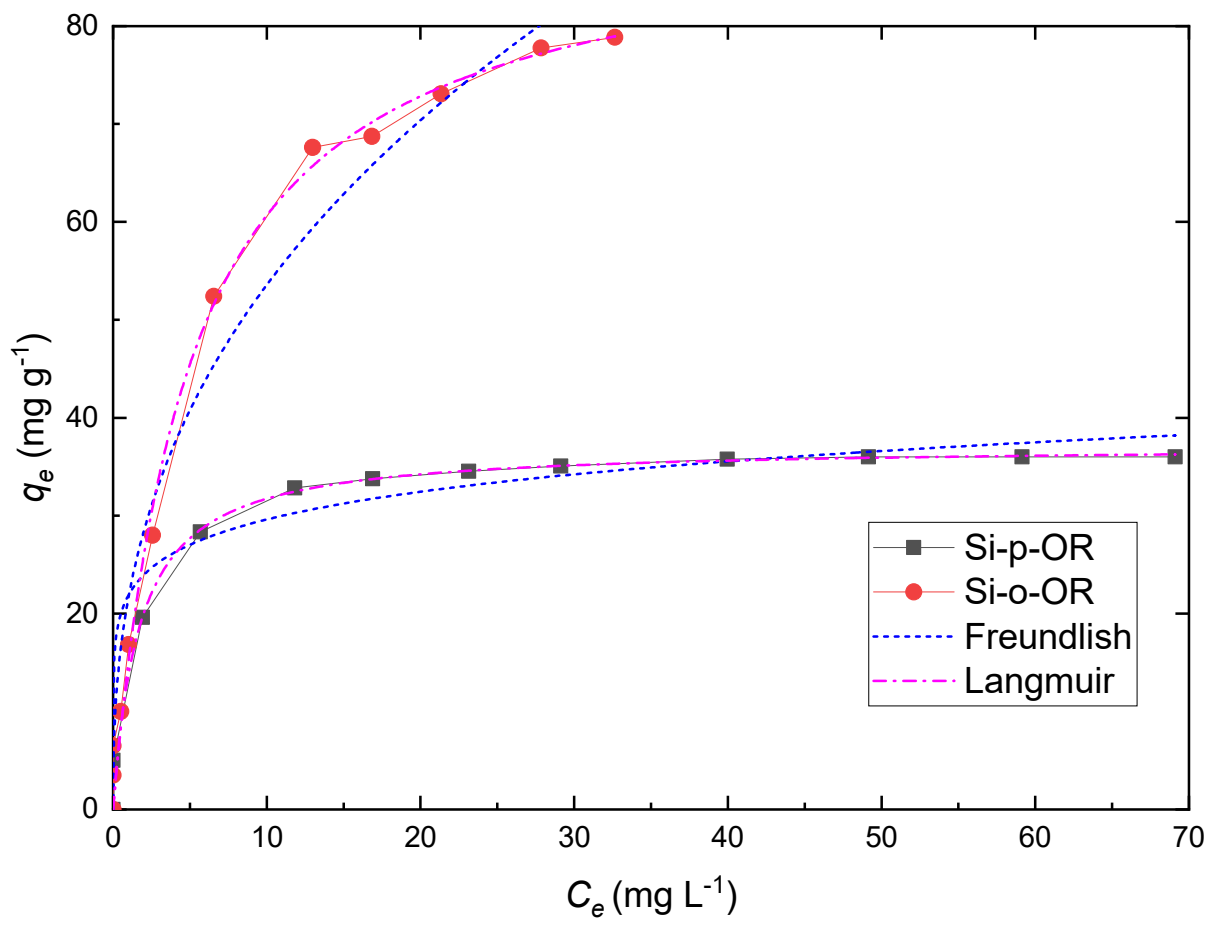

Figure 8. Effect of initial concentration on copper ion adsorption onto Si-o-OR and Si-p-OR and adsorption isotherms of both adsorbents towards $\mathrm{Cu}$ (II), fitted according to Langmuir and Freundlich models. Adsorption conditions: $10 \mathrm{mg}, \mathrm{V}=10 \mathrm{~mL},[\mathrm{Cu}(\mathrm{II})]=10$ to $300 \mathrm{mg} \mathrm{L}^{-1}, \mathrm{pH}=6$, time $=25 \mathrm{~min}$ at $25{ }^{\circ} \mathrm{C}$.

Fitting adsorption isotherms allows for the understanding of the interaction between adsorbate and adsorbent in the uptake process [33]. The most widely applied isotherm models are Langmuir and Freundlich. The nonlinear forms of Langmuir and Freundlich models can be obtained from the following Equations (6) and (7) [34,35].

Langmuir model:

$$
\mathrm{q}_{\mathrm{e}}=\mathrm{qK}_{\mathrm{L}} \mathrm{C}_{\mathrm{e}} / 1+\mathrm{k}_{\mathrm{L}} \mathrm{C}_{\mathrm{e}}
$$


Freundlich model:

$$
\mathrm{q}_{\mathrm{e}}=\mathrm{K}_{\mathrm{F}} \cdot \mathrm{C}_{\mathrm{e}}{ }^{1 / \mathrm{n}}
$$

where $\mathrm{q}_{\mathrm{e}}\left(\mathrm{mg} \mathrm{g}^{-1}\right)$ and $\mathrm{q}\left(\mathrm{mg} \mathrm{g}^{-1}\right)$ represent the equilibrium and the saturated adsorption capacity respectively; $\mathrm{K}_{\mathrm{L}}\left(\mathrm{L} \mathrm{mg}^{-1}\right)$ represents the Langmuir constant associated with the affinity of the adsorbent to the adsorbent; $\mathrm{K}_{\mathrm{F}}\left(\mathrm{mg} \mathrm{L}^{-1}\right)$ and $n$ are the Freundlich constants; and $\mathrm{C}_{\mathrm{e}}\left(\mathrm{mg} \mathrm{L}^{-1}\right)$ is the equilibrium concentration of metal ions.

The nonlinear fitting curves are illustrated in Figure 8, and the characteristic parameters of these models are shown in Table 2. As a result, the correlation coefficients of the Langmuir model $\left(R^{2}\right)$ were found to fit best. Moreover, the $q_{e}$ of both adsorbents evaluated by the Langmuir model is in agreement with the experimental value. These results demonstrate that the adsorption process is consistent with the Langmuir model of uniform monolayer sorption behaviour.

Table 2. Parameters for the Langmuir and Freundlich models of $\mathrm{Cu}(\mathrm{II})$ sorption.

\begin{tabular}{cccc}
\hline \multirow{2}{*}{ Model } & Parameters & \multicolumn{2}{c}{ Adsorbents } \\
\cline { 3 - 4 } & & Si-o-OR & Si-p-OR \\
\hline \multirow{3}{*}{ Langmuir } & $\mathrm{q}_{\exp }\left(\mathrm{mg} \mathrm{g}^{-1}\right)$ & 79.36 & 36.20 \\
& $\mathrm{qe}_{\mathrm{e}}\left(\mathrm{mg} \mathrm{g}^{-1}\right)$ & 88.00 & 36.00 \\
& $\mathrm{~K}_{\mathrm{L}}\left(\mathrm{L} \mathrm{mg}^{-1}\right)$ & 0.19 & 0.56 \\
\multirow{2}{*}{ Freundlich } & $\mathrm{R}^{2}$ & 0.99 & 0.98 \\
& $\mathrm{~N}$ & 2.50 & 7.50 \\
& $\mathrm{~K}_{\mathrm{F}}\left(\mathrm{mg} \mathrm{L}^{-1}\right)$ & 21.00 & 21.00 \\
& $\mathrm{R}^{2}$ & 0.97 & 0.96 \\
\hline
\end{tabular}

The determination of $\mathrm{q}_{\mathrm{e}}$ for $\mathrm{Cu}$ (II) with the adsorbents Si-o-OR and Si-p-OR led to $79.36 \mathrm{mg} \mathrm{g}^{-1}$ and $36.20 \mathrm{mg} \mathrm{g}^{-1}$ respectively. Thus, the adsorption capacity of Si-o-OR is at least twice higher compared to the Si-p-OR adsorbent. Such a superior adsorption capacity could be explained by the ortho-position of the ligand grafted onto the silica surface, which adapts a geometry more suitable for chelating complexations as compared to the Si-p-OR ligand.

\subsubsection{Adsorption Thermodynamics}

Thermodynamic studies were conducted to examine the effect of different temperatures on the sorption process. Thermodynamics parameters such as the Gibbs free energy change $\left(\Delta \mathrm{G}^{\circ}\right.$ in $\left.\mathrm{kJ} \mathrm{mol}^{-1}\right)$, the standard enthalpy of adsorption $\left(\Delta \mathrm{H}^{\circ}\right.$ in $\left.\mathrm{kJ} \mathrm{mol}{ }^{-1}\right)$, and the standard entropy change $\left(\Delta \mathrm{S}^{\circ}\right.$ in $\left.\mathrm{J} \mathrm{mol}^{-1} \mathrm{~K}^{-1}\right)$ were evaluated using Equations (8)-(10) [36,37]:

$$
\begin{gathered}
\mathrm{K}_{\mathrm{d}}=\mathrm{C}_{\mathrm{o}}-\mathrm{C}_{\mathrm{e}} / \mathrm{C}_{\mathrm{e}} \\
\operatorname{Ln} \mathrm{K}_{\mathrm{d}}=\Delta \mathrm{S}^{\circ} / \mathrm{R}-\Delta \mathrm{H}^{\circ} / \mathrm{RT} \\
\Delta \mathrm{G}^{\circ}=\Delta \mathrm{H}^{\circ}-\mathrm{T} \Delta \mathrm{S}^{\circ}
\end{gathered}
$$

where $\mathrm{R}\left(8.314 \mathrm{~J} \mathrm{~mol}^{-1} \mathrm{~K}^{-1}\right)$ is the ideal gas constant, $\mathrm{T}$ is the temperature in Kelvin and $\mathrm{K}_{\mathrm{d}}$ is the distribution coefficient. The numerical values of $\Delta \mathrm{H}^{\circ}$ and $\Delta \mathrm{S}^{\circ}$ could be obtained using the slope and intercept of the plot of $\ln \left(\mathrm{K}_{\mathrm{d}}\right)$ vs. $1 / T$. The results are given in Figure 9 and Table 3 . The values of $\Delta \mathrm{G}^{\circ}$ are all negative, indicating that the removal of $\mathrm{Cu}$ (II) on both adsorbents is a spontaneous process. Moreover, when the temperature increases, $\Delta \mathrm{G}^{\circ}$ gradually decreases, which signifies that higher temperatures favour adsorption. The positive value of $\Delta \mathrm{H}^{\circ}$ suggests the endothermic nature of the uptake process. As the values of $\Delta S^{\circ}$ are also positive, this implies that the sorption is an entropy-driven phenomenon [38]. The release of water molecules from the hydration shell of adsorbed metal ions may cause the chaotic degree of the whole aqueous system and lead to an entropy increase [39]. 


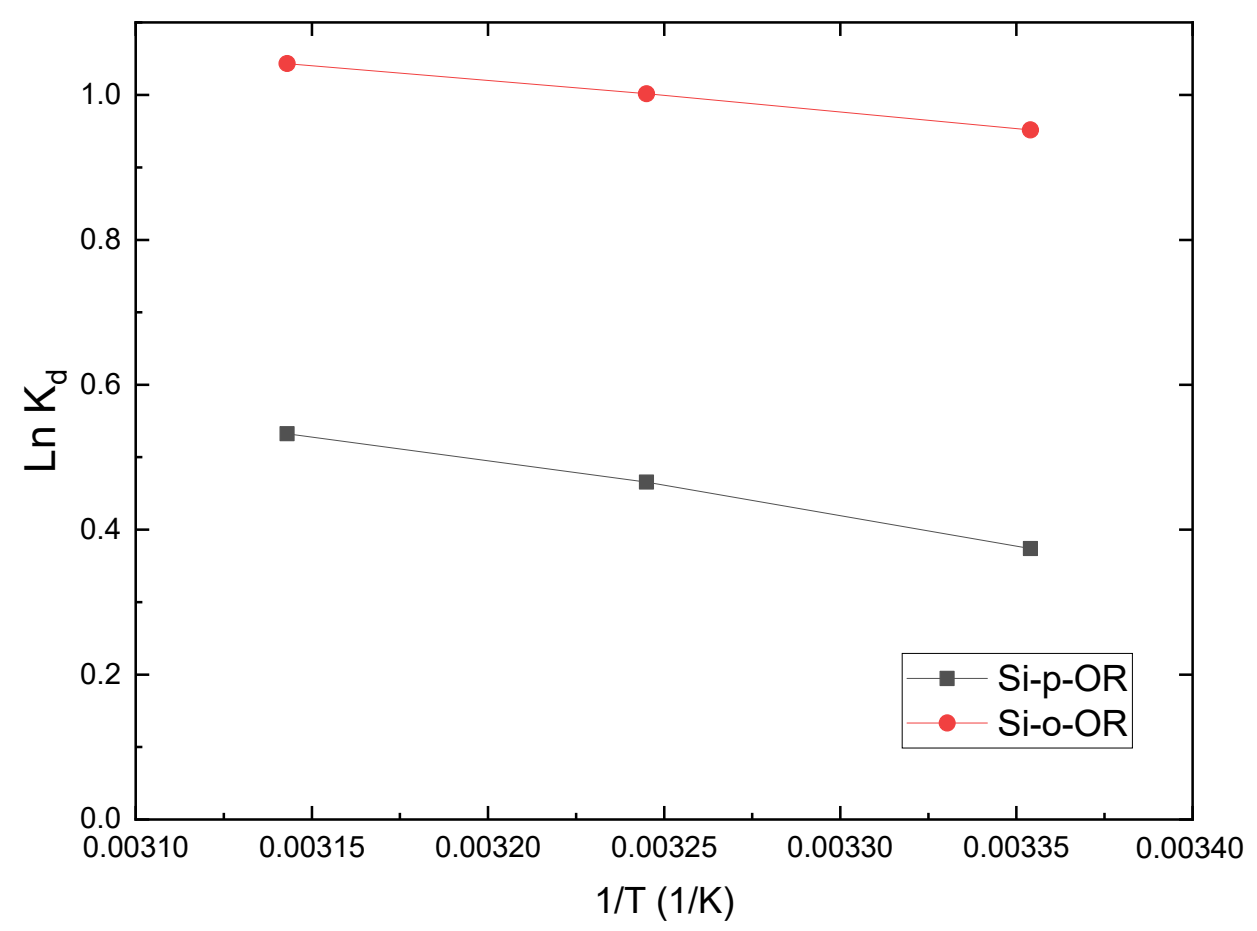

Figure 9. Linear plots of $\mathrm{K}_{\mathrm{d}}$ versus $1 / T$ for $\mathrm{Cu}(\mathrm{II})$ adsorption on Si-o-OR and Si-p-OR.

Table 3. Thermodynamic parameters of $\mathrm{Cu}(\mathrm{II})$ using Si-o-OR and Si-p-OR.

\begin{tabular}{|c|c|c|c|c|c|}
\hline \multirow{2}{*}{ Adsorbents } & \multirow{2}{*}{$\Delta \mathrm{H}^{\circ}\left(\mathrm{kJ} \mathrm{mol}^{-1}\right)$} & \multirow{2}{*}{$\Delta S^{\circ}\left(\mathrm{J} \mathrm{mol}^{-1} \mathrm{~K}^{-1}\right)$} & \multicolumn{3}{|c|}{$\Delta \mathrm{G}^{\circ}\left(\mathrm{kJ} \mathrm{mol}{ }^{-1}\right)$} \\
\hline & & & $299.15 \mathrm{~K}$ & $309.15 \mathrm{~K}$ & 319.15 \\
\hline Si-o-OR & 3.799 & 20.655 & -2.184 & -2.586 & -2.793 \\
\hline Si-p-OR & 6.986 & 26.543 & -0.955 & -1.219 & -1.485 \\
\hline
\end{tabular}

\subsubsection{Selectivity of Si-o-OR and Si-p-OR Adsorbents}

The removal selectivity of Si-o-OR and Si-p-OR adsorbents were examined by choosing $\mathrm{Cu}$ (II) as representative; $10 \mathrm{mg}$ of the adsorbent was added on $10 \mathrm{~mL}$ of mixed $\mathrm{Cu}(\mathrm{II})$, $\mathrm{Zn}(\mathrm{II}), \mathrm{Cd}(\mathrm{II})$, and $\mathrm{Pb}(\mathrm{II})$ quaternary systems with the same concentration $\left(120 \mathrm{mg} \mathrm{L}^{-1}\right)$ for competitive adsorption. As shown in Figure 10, Si-o-OR and Si-p-OR exhibit a higher adsorption selectivity for $\mathrm{Cu}(\mathrm{II})$ ion compared to other common divalent ions, such as $\mathrm{Zn}(\mathrm{II}), \mathrm{Cd}(\mathrm{II})$ and $\mathrm{Pb}(\mathrm{II})$. The excellent sorption selectivity of both adsorbents for $\mathrm{Cu}$ (II) can be explained by the ligands grafted onto the silica surface, which coordinate with $\mathrm{Cu}(\mathrm{II})$ to form more stable complexes. 


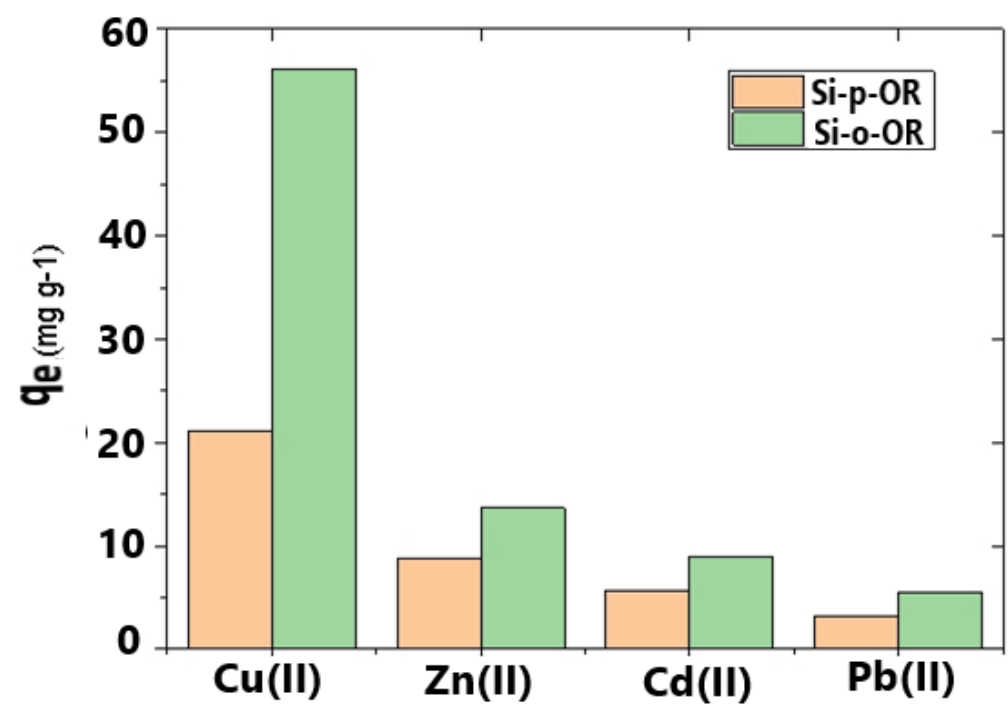

Figure 10. Metal ion selectivity effect using Si-o-OR and Si-p-OR.

\subsubsection{Effect of Coexisting Ions}

The presence of coexisting ions in water is another important factor influencing the adsorption and removal of $\mathrm{Cu}$ (II) ions. The effect of coexisting ions $\left(\mathrm{K}^{+}, \mathrm{Na}^{+}, \mathrm{Ca}^{2+}\right.$ and $\mathrm{Mg}^{2+}$ ) was investigated when the concentration of $\mathrm{Cu}(\mathrm{II})$ ions was maintained at $0.05 \mu \mathrm{g} \mathrm{mL}{ }^{-1}$. As presented in Table 4, the adsorption of $\mathrm{Cu}$ (II) was not weakened by any of the coexisting ions, which could not be complexed with both adsorbents.

Table 4. Effect of interfering ions on the recovery of $\mathrm{Cu}(\mathrm{II})$ ions adsorbed on both sorbents (concentration of $\mathrm{Cu}(\mathrm{II})$ ion is $0.05 \mu \mathrm{g} \mathrm{mL} \mathrm{m}^{-1}$ ).

\begin{tabular}{cccc}
\hline $\begin{array}{c}\text { Interfering } \\
\text { Metal Ions }\end{array}$ & $\begin{array}{c}\text { Concentration } \\
\left(\mu \mathbf{g ~ m L}^{-\mathbf{1}}\right)\end{array}$ & $\begin{array}{c}\text { Recovery of Cu(II) }(\%) \\
\text { for Si-o-OR }\end{array}$ & $\begin{array}{c}\text { Recovery of Cu(II) (\%) } \\
\text { for Si-p-OR }\end{array}$ \\
\hline $\mathrm{K}^{+}$ & 3000 & 97.89 & 95.98 \\
$\mathrm{Na}^{+}$ & 3000 & 97.76 & 94.89 \\
$\mathrm{Ca}^{2+}$ & 2000 & 95.87 & 92.45 \\
$\mathrm{Mg}^{2+}$ & 2000 & 96.65 & 91.65 \\
\hline
\end{tabular}

\subsubsection{Desorption and Recycling}

Reusability performance is an important factor for examining the extensive application of adsorbents; good recyclability can decrease costs and safeguard resources. The adsorbents Si-o-OR and Si-p-OR were evaluated in order to assess their ability to keep adsorption properties after five cycles of copper ion adsorption/desorption using $\mathrm{HCl}$ $(2 \mathrm{M})$ as the eluent (Table 5).

Table 5. Reusability and recycling of Si-o-OR and Si-p-OR adsorbents towards $\mathrm{Cu}(\mathrm{II})$ in repeated adsorption-desorption cycles.

\begin{tabular}{ccc}
\hline Cycle & $\begin{array}{c}\mathbf{q}_{\mathbf{e}}\left(\mathrm{mg} \mathrm{g}^{-\mathbf{1}}\right) \text { of Cu(II) Adsorbed on } \\
\text { Si-o-OR }\end{array}$ & $\begin{array}{c}\mathbf{q}_{\mathbf{e}}\left(\mathbf{m g ~ g}^{-\mathbf{1}}\right) \text { of Cu(II) Adsorbed on } \\
\text { Si-p-OR }\end{array}$ \\
\hline 1 & 79.36 & 36.20 \\
2 & 79.04 & 36.06 \\
3 & 79.16 & 35.87 \\
4 & 77.04 & 34.74 \\
5 & 76.89 & 33.98 \\
\hline
\end{tabular}

After five cycles, both adsorbents retained almost $95 \%$ of their initial adsorption capacity for $\mathrm{Cu}$ (II) ions, which indicates that the $\mathrm{HCl}$ solution is efficient for the regeneration 
of $\mathrm{Cu}$ (II) loaded onto Si-o-OR and Si-p-OR. These adsorbents have good regeneration and are promising for the adsorption of $\mathrm{Cu}$ (II) ions from waste water.

\subsubsection{Application to Real Water Treatment}

In order to check whether our adsorbent is applicable to real water samples, we selected two samples originating from two different Moroccan rivers: (i) the Ghiss river (located next to $\mathrm{Al}$ Hoceima), which demonstrated a $\mathrm{pH}=7.7$, total dissolved solids (TDS) $=1297 \mathrm{mg} \mathrm{L}^{-1}$ and conductivity $\sigma=1733 \mu \mathrm{S} \mathrm{cm}{ }^{-1}$; and (ii) the Toussit-Boubekker river (in the Jerada-Oujda region), which demonstrated a $\mathrm{pH}=7.1$, TDS $=2031 \mathrm{mg} \mathrm{L}^{-1}$ and $\sigma=2301 \mu \mathrm{S} \mathrm{cm}^{-1}$. The adsorption capacities of Si-o-OR and Si-p-OR (10 mg) were studied under optimal conditions by the batch method using river water $(10 \mathrm{~mL})$. As can be seen in Table 6, the removal efficiency of $\mathrm{Cu}$ (II) ions as demonstrated by Si-o-OR was as high as $92 \%$ and $94 \%$ from the Ghiss and Toussit-Boubekker rivers, respectively. On the other hand, the percentage of removal demonstrated by Si-p-OR of $82 \%$ and $84 \%$ from the Ghiss and Toussit-Boubekker rivers, respectively, confirmed that this method had satisfactory recoveries and good accuracy. The results clearly indicate that the Si-o-OR material is an excellent candidate in the purification of real water samples.

Table 6. Removal of copper from real wastewater samples using Si-o-OR and Si-p-OR.

\begin{tabular}{cccc}
\hline Rivers & $\begin{array}{c}\text { Added } \mathbf{C u}(\mathrm{II}) \\
\left.\mathbf{( m g ~ L}^{-\mathbf{1}}\right)\end{array}$ & $\begin{array}{c}\text { Percentage of Removal } \\
\text { Efficiency (\%) Si-o-OR }\end{array}$ & $\begin{array}{c}\text { Percentage of Removal } \\
\text { Efficiency (\%) Si-p-OR }\end{array}$ \\
\hline $\begin{array}{c}\text { Ghiss } \\
\text { Toussit- }\end{array}$ & 10 & 92.06 & 82.16 \\
Boubekker & 10 & 93.87 & 84.65 \\
\hline
\end{tabular}

\subsubsection{Comparison with Similar Adsorbents}

A comparison of the performance of our adsorbents towards $\mathrm{Cu}(\mathrm{II})$ to literature examples reveal higher characteristics; in particular, Si-o-OR can be considered a promising candidate for wastewater treatment (Table 7).

Table 7. Comparison of the maximum adsorption capacities of $\mathrm{Cu}$ (II) by different adsorbents reported in the literature.

\begin{tabular}{|c|c|c|}
\hline Silica Gel-Ligand & Reference & Metal Ion (mg g $\left.{ }^{-1}\right)$ \\
\hline Si-o-OR & This work & 79.36 \\
\hline Si-p-OR & This work & 36.20 \\
\hline Porphyrin & [40] & 19.08 \\
\hline N-propyl-2-pyridylimine & [41] & 35.63 \\
\hline Methyl methacrylate & [42] & 41.36 \\
\hline Dithiocarbamate & [43] & 25.00 \\
\hline p-toluenesulfonylamide & {$[44]$} & 05.00 \\
\hline $\begin{array}{l}\text { 3-Hydroxysalicylaldiminepropyl } \\
\text { triethoxysilane }\end{array}$ & [45] & 05.72 \\
\hline Furan ketonenol & [46] & 31.82 \\
\hline 3-amino-1,2-propanediol & [47] & 31.18 \\
\hline Commercial Lewatit (L-207) & [48] & 68.09 \\
\hline Bis(pyrazole) & [49] & 20.24 \\
\hline
\end{tabular}

\subsection{Adsorption Mechanism}

The adsorption mechanism was studied by combined FTIR, energy dispersive X-ray fluorescence (EDX) and computational methods.

\subsubsection{Energy Dispersive X-ray Fluorescence (EDX)}

$\mathrm{Cu}$ (II) ions were detected after complexation as shown by comparison of EDX data of both adsorbents before and after copper ion adsorption (Figure 11). Indeed, no $\mathrm{Cu}(\mathrm{II})$ was 
detected in the composition of $\mathbf{S i - o - O R}$ and $\mathbf{S i - p - O R}$ before adsorption, whereas it reaches $8.93 \%$ and $15.94 \%$ for Si-p-OR and Si-o-OR, respectively.
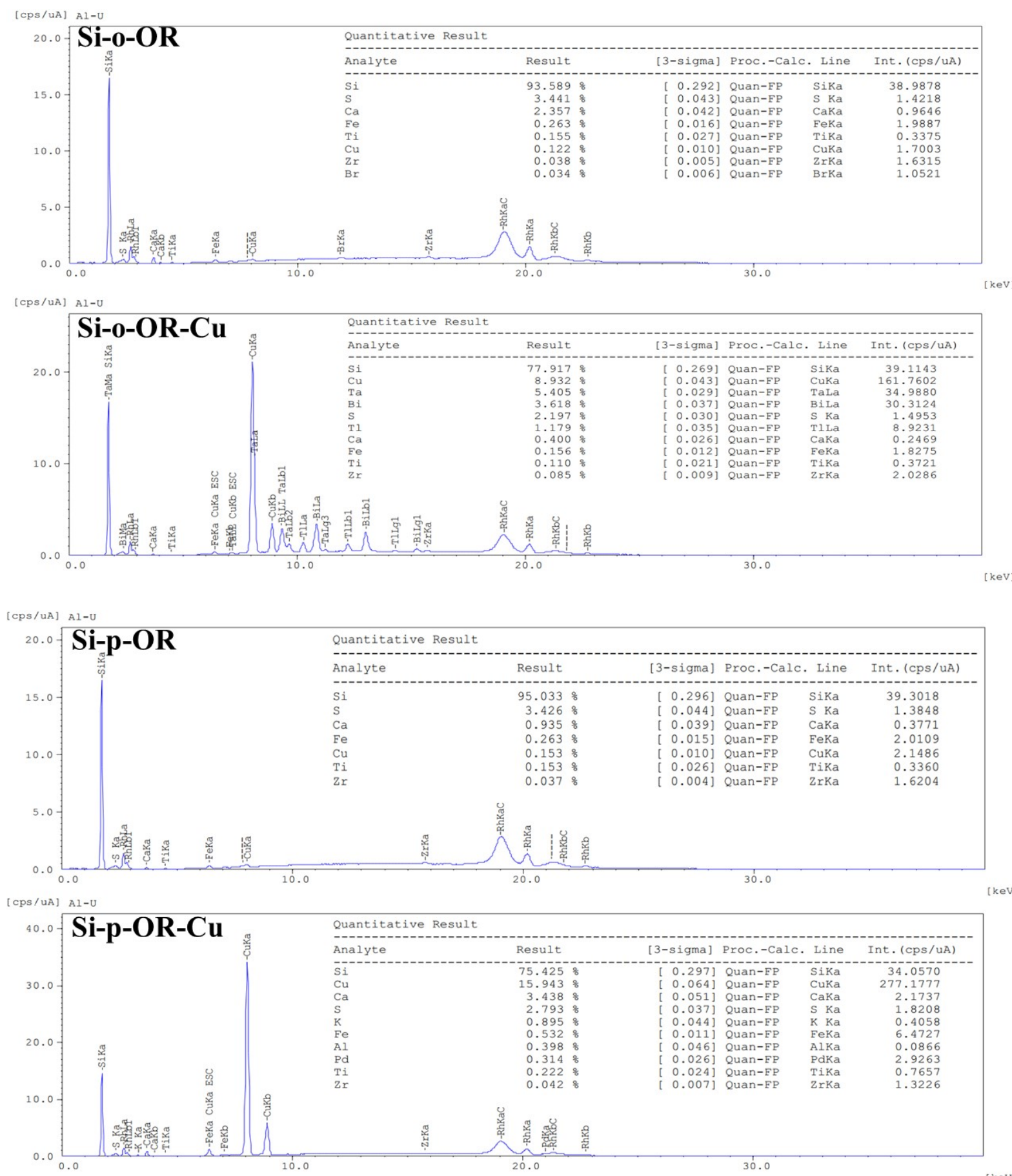

Figure 11. EDX spectra of Si-o-OR and Si-p-OR (before adsorption) and Si-o-OR-Cu and Si-p-OR-Cu (after adsorption of $\mathrm{Cu}(\mathrm{II}))$.

\subsubsection{Fourier Transformed Infrared Spectroscopy}

Figure 12 shows FTIR spectra of Si-o-OR and Si-p-OR before and after adsorption. The peak at $1460 \mathrm{~cm}^{-1}$ belonging to the $\mathrm{N}=\mathrm{C}$ group becomes weaker after adsorption of $\mathrm{Cu}$ (II) ions, and is shifted downwards at $1976 \mathrm{~cm}^{-1}$, demonstrating the participation of $\mathrm{N}=\mathrm{C}$ groups in the coordination of $\mathrm{Cu}(\mathrm{II})$ ions for both hybrid materials. 


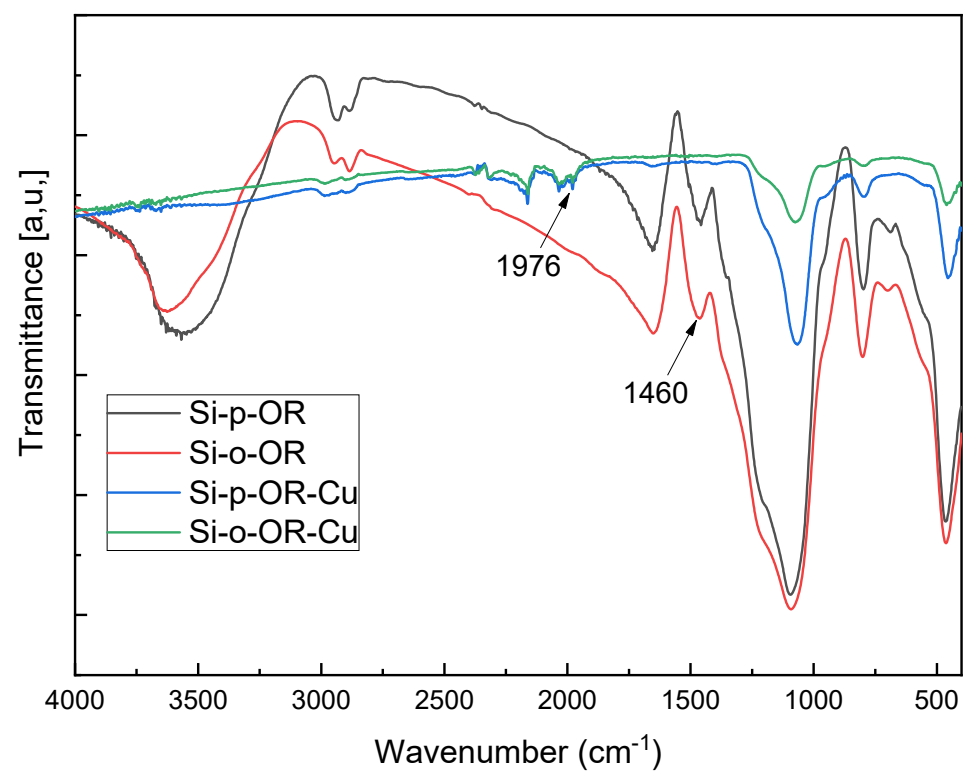

Figure 12. FTIR spectra before and after coordination with $\mathrm{Cu}(\mathrm{II})$ for Si-o-OR and Si-p-OR.

\subsubsection{Theoretical Investigations}

MASD and QTAIM Calculations of Schiff Bases

Nucleophilic Parr indices (P-) are needed to evaluate the electron donating ability of atomic sites of donor species. These indices are obtained in terms of the Mulliken atomic spin density (MASD) analysis by removing an electron from the Schiff base molecule. Optimized structures of Schiff bases (Si-p-OR and Si-o-OR) and $p$-values of donor atoms are shown in Figure 13. Local reactivity was supported by QTAIM calculations of the non-bonding electron density (NBED). In particular, the NBED considers the overlap of an empty $3 \mathrm{~d}$ orbital of $\mathrm{Cu}$ (II) to form chemical bonds. NBED values were therefore gathered on the same Figure 13 for completeness.

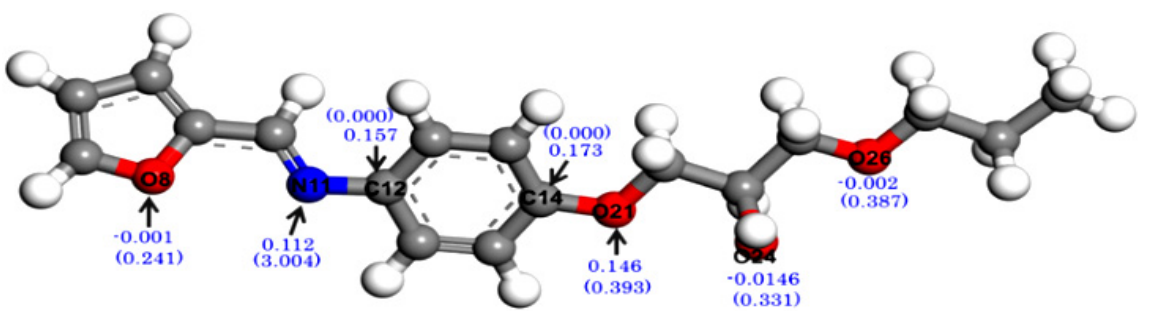

Si-p-OR

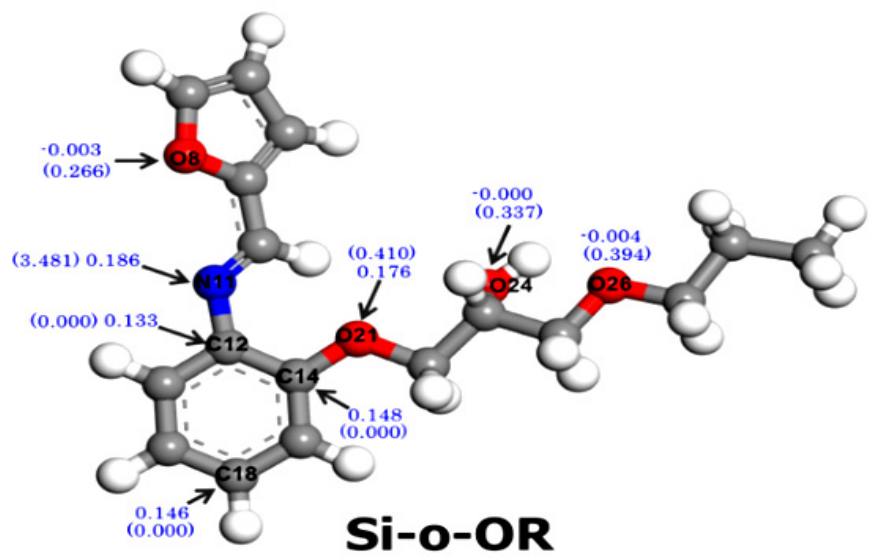

Figure 13. Optimized structures and $p$-values of significant atoms of Schiff bases. NBED values are given between parentheses. 
Three oxygen atoms $(\mathrm{O} 8, \mathrm{O} 24$ and $\mathrm{O} 26)$ are not considered to be reactive (P- being zero or negative), which indicate that they are not involved in coordination with $\mathrm{Cu}(\mathrm{II})$. Nevertheless, a nitrogen (N11) and oxygen (O21) atom display high values of $\mathrm{P}_{-}$, indicating that these are suitable sites for an electrophilic attack via $\mathrm{Cu}$ (II) ions. This result was reinforced by QTAIM calculations of non-bonding electron density that aimed to describe the electron density population for each atomic space of Si-p-OR and Si-o-OR based on the delocalized and localized index measurements of the electron density, which is shared or exchanged between two atoms.

According to Figure 13, the most preferred active interaction sites of Si-p-OR and Si-o-OR are nitrogen atoms (N11) of the azomethine group, since their NBED values are important enough ( $>3$ e) to establish orbital bonds with $\mathrm{Cu}(\mathrm{II})$. The situation differs for oxygen atoms $(\mathrm{O} 8, \mathrm{O} 21, \mathrm{O} 26$ and $\mathrm{O} 28)$, because their NBED is not sufficient to create a novel orbital bond with the vacant $d$ orbital $(<2 \mathrm{e})$. In other words, the nitrogen atom N11 of Si-o-OR displays a higher value of NBED than that of Si-p-OR, which indicates a strong coordination of $\mathrm{Cu}(\mathrm{II})$ with Si-o-OR.

\section{$\mathrm{Cu}$ (II) Complexation Study}

The fully optimized geometries of possible complexes are proposed on the basis of $\mathrm{P}$ - indices and NBO analysis. In this sense, $\Delta \mathrm{G}_{\mathrm{C}}$ was calculated, which is the variation of free energy accompanying the transformation of reactant species ( $\mathrm{Cu}(\mathrm{II})$ and Schiff base) to form metal complexes. Free energies of complexation $\left(\Delta \mathrm{G}_{\mathrm{C}}\right)$ of the proposed complexes, i.e., those related to the coordination of $\mathrm{N} 11-\mathrm{Cu}(\mathrm{II})$ and $\mathrm{Cu}(\mathrm{II})-\mathrm{O} 21$, are gathered in Table 8 .

Table 8. Gibbs free energies of complexation $\left(\Delta G_{C}\right)$ for the studied complexes.

\begin{tabular}{|c|c|c|}
\hline & $\begin{array}{c}\Delta \mathrm{G}_{\mathrm{C}}\left(\mathrm{kcal} \mathrm{mol}^{-1}\right) \\
\quad(\mathrm{Cu}-\mathrm{N} 11)\end{array}$ & $\begin{array}{c}\Delta \mathrm{G}_{\mathrm{C}}\left(\mathrm{kcal} \mathrm{mol}^{-1}\right) \\
\quad(\mathrm{Cu}-\mathrm{O} 21)\end{array}$ \\
\hline Cu-Si-p-OR & -25.264 & -05.115 \\
\hline Cu-Si-o-OR & -112.73 & -13.52 \\
\hline
\end{tabular}

As shown in Table 8, the formation of the four proposed complexes takes place spontaneously $\left(\Delta \mathrm{G}_{\mathrm{C}}<0\right)$. The comparison of $\Delta \mathrm{G}_{\mathrm{C}}$ values indicates that the complexes Cu-N11(Sip-OR) and $\mathbf{C u}-\mathbf{N 1 1 ( S i - o - O R ) ~ p r e s e n t ~ t h e ~ l o w e s t ~} \Delta \mathrm{G}_{\mathrm{C}}$ attesting the higher stability of these complexes. In addition, the $\Delta \mathrm{G}_{\mathrm{C}}$ corresponding to the formation of $\mathbf{C u}-\mathbf{N 1 1 ( S i - o - O R )}$ is much lower $\left(-112.73{\left.\mathrm{kcal} . \mathrm{mol}^{-1}\right)}^{-1}\right.$ than that of $\mathbf{C u}-\mathbf{O} 21(\mathbf{S i - o - O R})\left(-13.52 \mathrm{kcal}^{-\mathrm{mol}^{-1}}\right)$, which demonstrates that $\mathbf{C u}-\mathbf{N 1 1}(\mathrm{Si}-\mathbf{o}-\mathbf{O R})$ is more stable; this could be explained by the fact that the OR group has a high electron donating character in the ortho position compared to the para position. These results indicate that Si-o-OR is an excellent coordinating ligand to $\mathrm{Cu}(\mathrm{II})$, which explains its high capacity to capture this metal ion from aqueous solutions as observed experimentally.

Figure 14 shows that the complexation of $\mathrm{Cu}(\mathrm{II})$ with water molecules was also considered for the complexation modes $\mathbf{C u - N 1 1 ( S i - p - O R ) ~ a n d ~ C u - N 1 1 ( S i - o - O R ) . ~ B o t h ~ d i s t a n c e ~}$ and binding energy (BE) of the length between nitrogen atoms of azomethine groups and copper atoms are also shown in Figure 14. Both Si-p-OR and Si-o-OR coordinate with $\mathrm{Cu}$ (II) using its nitrogen atom of azomethine groups and the oxygen atom of water molecules to form stable complexes $\left(\mathbf{H}_{2} \mathbf{O}-\mathbf{C u}-\mathbf{N 1 1}-\mathrm{Si}-\mathrm{p}-\mathrm{OR}\right.$ and $\left.\mathbf{H}_{\mathbf{2}} \mathbf{O}-\mathrm{Cu}-\mathrm{N} 11-\mathrm{Si}-\mathrm{O}-\mathrm{OR}\right)$; consequently, Si-p-OR/or Si-o-OR chelate with $\mathrm{Cu}(\mathrm{II})$, affording a monodentate mode. It is worthy to mention that the BE related to the N11-Cu interaction for Si-p-OR and Si-o-OR is 37.53 and $43.93 \mathrm{kcal} / \mathrm{mol}$, respectively; this suggests that the nitrogen atom of the azomethine group coordinates strongly with $\mathrm{Cu}(\mathrm{II})$ when the OR group is in the ortho position of phenyl than in the para position. 


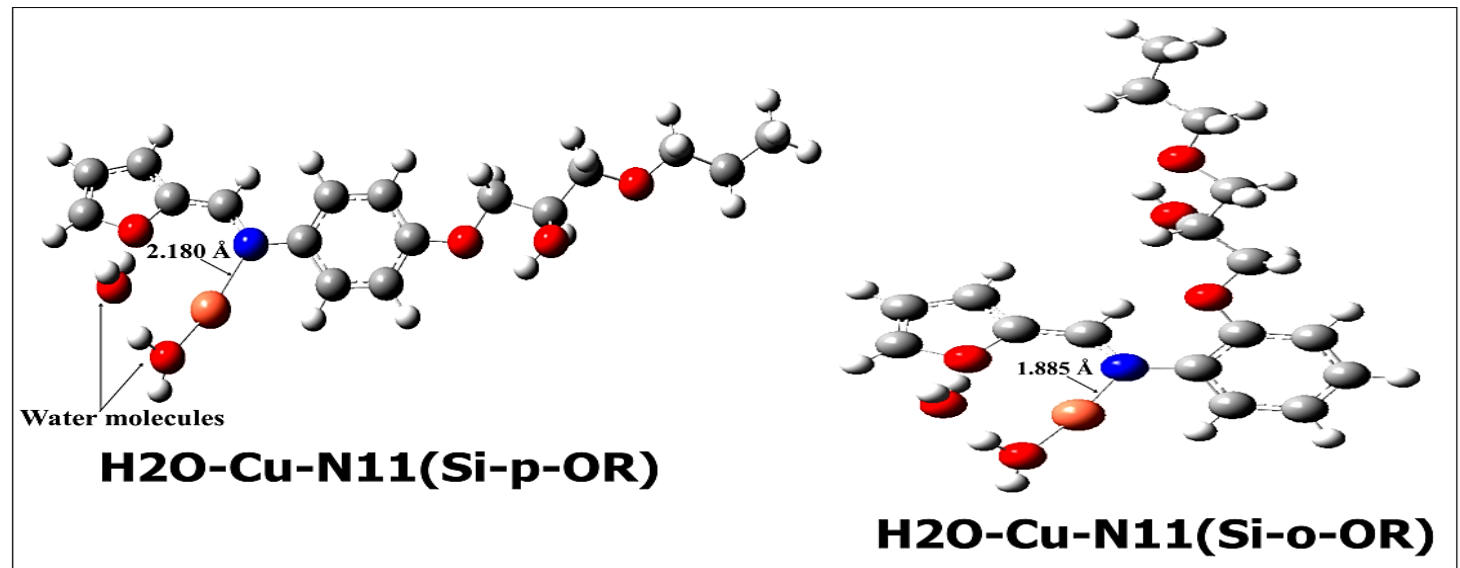

Figure 14. $\mathrm{H}_{2} \mathrm{O}-\mathrm{Cu}-\mathrm{N} 11(\mathrm{Si}-\mathrm{p}-\mathrm{OR})$ and $\mathrm{H}_{2} \mathrm{O}-\mathrm{Cu}-\mathrm{N} 11(\mathrm{Si}-\mathbf{o}-\mathrm{OR})$ complexes.

NBO analysis allows us to study the strength of the coordination of nitrogen atoms (N11) with $\mathrm{Cu}(\mathrm{II})$ for the two studied complexes (Figure 14) with the calculation of second order stabilization energy $\mathrm{E}^{(2)}$ and the electronic configurations of $\mathrm{Cu}$ and N11 including these complexes (Table 9). Since a large value of $\mathrm{E}^{(2)}$ means a more intensive donor-acceptor interaction, this value is considered to be a good representation of the bond strength. According to Table 9, the valence electronic configuration of N11 in the two studied complexes ranged as follows: $\mathrm{EC}\left(\mathrm{H}_{2} \mathrm{O}-\mathrm{Cu}-\mathrm{N} 11\right.$ (Si-o-OR) $<\mathrm{EC}\left(\mathrm{H}_{2} \mathrm{O}-\mathrm{Cu}-\mathrm{N} 11\right.$ (Si-p-OR). For $\mathrm{Cu}$, its electronic configuration varies as: $\mathrm{EC}\left(\mathrm{H}_{2} \mathrm{O}-\mathrm{Cu}-\mathrm{N} 11(\mathrm{Si}-\mathrm{p}-\mathrm{OR})<\mathrm{EC}\left(\mathrm{H}_{2} \mathrm{O}-\mathrm{Cu}-\right.\right.$ $\mathrm{N} 11$ (Si-o-OR). This supports the theory that there is a charge transfer process which takes place from $\mathrm{N} 11$ to the d-empty orbital of $\mathrm{Cu}(\mathrm{II})$, on which the coordination $\mathrm{H}_{2} \mathrm{O}-\mathrm{Cu}-\mathrm{N} 11$ (Sio-OR) is preferred. Otherwise, the calculated stabilization energies $\mathrm{E}^{(2)}$ show that the interaction strength NBED of $\mathrm{N} 11 \rightarrow \mathrm{Cu}(\mathrm{II})$ follows the trend: $\mathrm{E}^{(2)}\left(\mathrm{H}_{2} \mathrm{O}-\mathrm{Cu}-\mathrm{N} 11(\mathrm{Si}-\mathbf{o}-\mathrm{OR})>\right.$ $\mathrm{E}^{(2)}\left(\mathrm{H}_{2} \mathrm{O}-\mathrm{Cu}-\mathrm{N} 11(\mathrm{Si}-\mathrm{p}-\mathrm{OR})\right.$.

Table 9. $\mathrm{E}^{(2)}$ energy calculation $(\mathrm{kcal} / \mathrm{mol})$ related to the coordination of NBED of N11 with 3d-empty orbital (3DEO) of $\mathrm{Cu}(\mathrm{II})$.

\begin{tabular}{|c|c|c|}
\hline & $\begin{array}{l}\text { Electronic Configuration } \\
\text { (for } \mathrm{Cu} \text { and N11) }\end{array}$ & $\mathrm{E}^{(2)}$ of $\mathrm{NBED} \rightarrow 3 \mathrm{DEO}$ \\
\hline $\mathrm{H}_{2} \mathrm{O}-\mathrm{Cu}-\mathrm{N} 11(\mathrm{Si}-\mathrm{p}-\mathrm{OR})$ & $\begin{array}{c}\text { Cu: }[\text { core }] 4 s^{0.17} 3 \mathrm{~d}^{4.93} 4 \mathrm{p}^{0.06} \\
\text { N11:[core }] 2 \mathrm{~s}^{1.41} 2 \mathrm{p}^{5.02} 3 \mathrm{p}^{0.01}\end{array}$ & 37.53 \\
\hline H2O-Cu-N11(Si-o-OR) & $\begin{array}{c}\text { Cu:[core] } 4 \mathrm{~s}^{0.19} 3 \mathrm{~d}^{7.88} 4 \mathrm{p}^{0.08} \\
\mathbf{N 1 1}:\left[\text { core] } 2 \mathrm{~s}^{1.41} 2 \mathrm{p}^{5.09} 3 \mathrm{p}^{0.01}\right.\end{array}$ & 43.93 \\
\hline
\end{tabular}

According to our computations, the OR group contributes its electronic density with the phenyl group because of its important mesomeric effect $(+\mathrm{M})$ (an electron donating effect). In addition, the mesomeric effect (+M) of the OR group, as well as the coordination of nitrogen atoms of azomethine, is more favoured when OR is in the ortho position substituted on phenyl compared to the para position. Furthermore, the oxygen atom of the furan group contributes to its electronic density only with atoms of the furan ring.

\section{NBI Analysis of $\mathrm{H}_{2} \mathrm{O}-\mathrm{Cu}-\mathrm{N} 11$ (Si-p-OR/or Si-o-OR) Complexes}

$\mathrm{NBO}$ was undertaken to characterize the nature of no-binding interactions, commonly defined as strong attractive interactions (in blue), weak interactions (in green) and repulsive interactions. Figure 15 shows the NBI shapes of the two complexes $\mathbf{H}_{\mathbf{2}} \mathbf{O}-\mathbf{C u}-\mathbf{N 1 1}(\mathrm{Si}-\mathbf{p}-\mathbf{O R})$ and $\mathbf{H}_{\mathbf{2}} \mathrm{O}-\mathrm{Cu}-\mathbf{N 1 1}(\mathrm{Si}-\mathbf{o}-\mathrm{OR})$; their abbreviation in this section is NBI/para and NBI/ortho, respectively. 


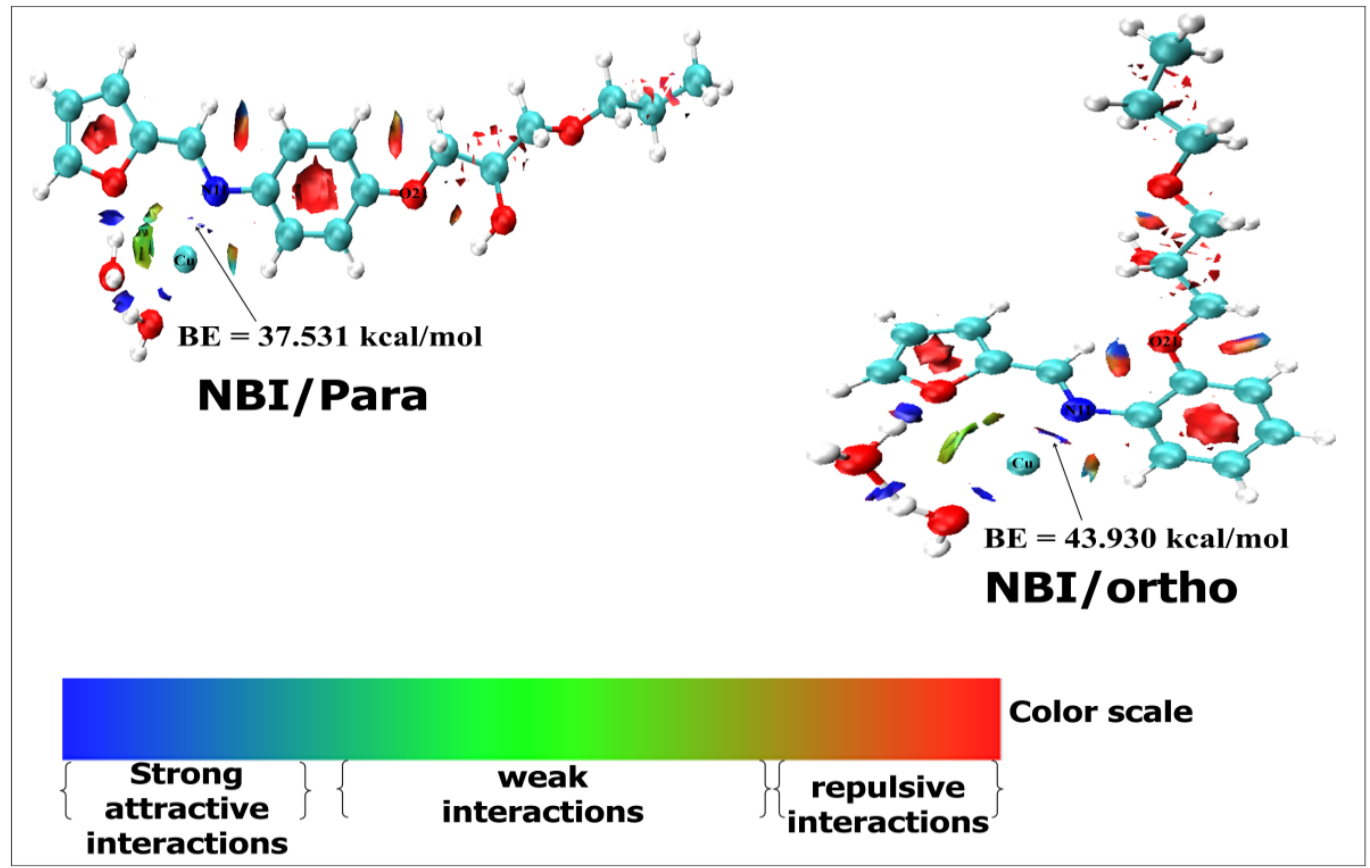

Figure 15. NBI analysis of two complexes: $\mathrm{H}_{2} \mathrm{O}-\mathrm{Cu}-\mathrm{N} 11(\mathrm{Si}-\mathrm{p}-\mathrm{OR})$, noted NBI/para, and $\mathrm{H}_{2} \mathrm{O}-\mathrm{Cu}-\mathrm{N} 11(\mathrm{Si}-\mathrm{o}-\mathrm{OR})$, noted NBI/ortho.

The stronger interaction is found between the nitrogen atom (N11) of azomethine groups and copper atoms. Moreover, the oxygen atom of the furan group is connected with hydrogen atoms of the water media through a strong interaction process. This interaction is more favoured for the ortho mode of complexation: i.e., $\mathbf{H}_{\mathbf{2}} \mathbf{O}-\mathbf{C u}-\mathbf{N 1 1}(\mathrm{Si}-\mathbf{o}-\mathrm{OR})$ than for the para mode of complexation: i.e., $\mathbf{H}_{\mathbf{2}} \mathbf{O}-\mathbf{C u}-\mathbf{N 1 1 ( S i - p - O R ) . ~ F u r t h e r m o r e , ~ F i g u r e ~} 15$ clearly discloses that oxygen atom (O21) coordination with $\mathrm{Cu}(\mathrm{II})$ becomes very difficult (presence of repulsive interaction). This result is in good agreement with those found in the theories based on the DFT calculations (MASD, QTAIM and NBO).

Adsorption Selectivity: NBO Analysis

In this section, NBO analysis was carried out to determine occupancy of d-atomic orbitals of metal ion and their energy. Table 10 shows the occupancy of d-atomic orbitals as valence orbitals (VO) and their energy for studied metal ions $\mathrm{Cu}(\mathrm{II}), \mathrm{Zn}(\mathrm{II}), \mathrm{Cd}(\mathrm{II})$ and $\mathrm{Pb}(\mathrm{II})$. Table 11 shows the energy of VO nitrogen atom N11 as the active centre of Si-o-OR and Si-p-OR.

Table 10. d-atomic orbital (d-OA) occupancies (in e) for metal ions.

\begin{tabular}{cccccc}
\hline $\mathbf{d}-\mathbf{O A}$ & $\mathbf{d}_{\mathbf{x y}}$ & $\mathbf{d}_{\mathbf{x z}}$ & $\mathbf{d}_{\mathbf{y z}}$ & $\mathbf{d}_{\mathbf{x} 2 \mathbf{y} \mathbf{2}}$ & $\mathbf{d}_{\mathbf{z} \mathbf{2}}$ \\
\hline & & \multicolumn{5}{c}{ Occupancy } \\
\hline $\mathrm{Cu}(\mathrm{II})$ & 1.000 & 0.999 & 1.000 & 0.249 & 0.749 \\
\hline $\mathrm{Zn}(\mathrm{II})$ & 2.000 & 2.000 & 2.000 & 2.000 & 2.000 \\
\hline $\mathrm{Cd}(\mathrm{II})$ & 2.000 & 2.000 & 2.000 & 2.000 & 2.000 \\
\hline $\mathrm{Pb}(\mathrm{II})$ & 1.999 & 1.999 & 1.999 & 1.999 & 0.000 \\
\hline & & & & \\
\hline $\mathrm{Cu}(\mathrm{II})$ & -0.989 & -1.036 & -1.092 & -1.092 & -1.036 \\
\hline $\mathrm{Zn}(\mathrm{II})$ & -1.204 & -1.154 & -1.204 & -1.009 & -1.106 \\
\hline $\mathrm{Cd}(\mathrm{II})$ & -1.277 & -1.277 & -1.277 & -1.277 & -1.277 \\
\hline $\mathrm{Pb}(\mathrm{II})$ & -1.329 & -1.329 & -1.329 & -1.329 & -1.329 \\
\hline
\end{tabular}


Table 11. VO energies of N11 for Si-o-OR and Si-p-OR (in a.u.).

\begin{tabular}{ccccc}
\hline Ligand & $\mathbf{2 s}$ & $\mathbf{2} \mathbf{p}_{\mathbf{x}}$ & $\mathbf{2} \mathbf{p}_{\mathbf{y}}$ & $\mathbf{2} \mathbf{p}_{\mathbf{z}}$ \\
\hline N11(Si-o-OR) & -0.337 & -0.176 & -0.208 & -0.189 \\
\hline N11(Si-p-OR) & -0.503 & -0.194 & -0.135 & -0.167 \\
\hline
\end{tabular}

The occupancy of d-atomic orbitals for the studied metal ions increases following the trend: $\mathrm{Pb}$ (II) $<\mathrm{Cu}$ (II) $<\mathrm{Cd}(\mathrm{II}) \approx \mathrm{Zn}$ (II) (Table 10). In addition, we noticed that VO energy levels of $\mathrm{N} 11$ for the two studied ligands near to those of metal ions are as follows: $\mathrm{Cu}$ (II) $<\mathrm{Zn}$ (II) $<\mathrm{Cd}$ (II) $<\mathrm{Pb}$ (II) (Table 11). Since the orbital interactions will be favourable when their energy levels are closer to each other, we can conclude that the selectivity of the ligand toward metal ions increases as follows: $\mathrm{Cu}$ (II) $>\mathrm{Zn}(\mathrm{II})>\mathrm{Cd}(\mathrm{II})>\mathrm{Pb}$ (II). This is in good agreement with the selectivity order observed experimentally (Figure 10).

\section{Materials and Methods}

\subsection{Reagents and Materials}

Silica gel, furfural, 4-aminophenol, 2-aminophenol, 3-glycidoxypropyl trimethoxysilane, sodium (Na), ethanol, methanol, toluene, acetic acid, tetrahydrofurane (THF), dimethylformamide (DMF), sodium hydroxide $(\mathrm{NaOH})$, hydrochloric acid $(\mathrm{HCl})$ and $\mathrm{Cu}\left(\mathrm{NO}_{3}\right)_{2} \cdot 2 \mathrm{H}_{2} \mathrm{O}$ were purchased from Sigma Aldrich. Silica gel with a particle size in the range of 70-230 mesh, surface area of $470-530 \mathrm{~m}^{2} \mathrm{~g}^{-1}$, pore diameter of $52-73 \AA$, and pore volume of $0.7-0.85 \mathrm{~cm}^{3} \mathrm{~g}^{-1}$ was activated before use by heating at $120^{\circ} \mathrm{C}$ for $24 \mathrm{~h}$. The silylating agent 3-glycidoxypropyltrimethoxysilane was used without purification.

\subsection{Experimental}

3.2.1. Preparation of Adsorbents

a-Synthesis of the Furan Derivatives

The ligands were synthesized using similar procedures to those described in previous reports [50,51]. Typically, a solution of furan-2-carbaldehyde (2 $\mathrm{g}, 20.3 \mathrm{mmol})$ and 4-aminophenol ( $2.3 \mathrm{~g}, 20.3 \mathrm{mmol})$ or 2-aminophenol in $20 \mathrm{~mL}$ of dry ethanol using 2-3 drops of acetic acid was stirred under reflux for $3 \mathrm{~h}$. The resulting solids were filtered, and then crude compounds were recrystallized with hot methanol.

(E)-4-(furan-2-ylmethyleneamino) phenol, yellow powder, yield 63\% (2.4 g, $12.82 \mathrm{mmol})$. m.p. $198-199{ }^{\circ} \mathrm{C}$. $\mathrm{R}_{\mathrm{f}}=0.5$ (silica, $\left.\mathrm{CH}_{2} \mathrm{Cl}_{2} / \mathrm{MeOH}, 9 / 1\right) .{ }^{1} \mathrm{H}$ NMR (300 MHz, DMSO) $\delta$ ppm: $9.52(\mathrm{~s}, 1 \mathrm{H}, \mathrm{OH}) ; 8.39(\mathrm{~s}, 1 \mathrm{H}, \mathrm{CH}=\mathrm{N}) ; 7.85(\mathrm{~d}, 1 \mathrm{H}$, furan- $\mathrm{H} \alpha) ; 7.15\left(\mathrm{~d}, 2 \mathrm{H}\right.$, phenyl, $\mathrm{C}_{2} \mathrm{H}$, $\left.\mathrm{C}_{3} \mathrm{H}\right) ; 7.03(\mathrm{~d}, 1 \mathrm{H}$, furan- $\mathrm{H} \gamma) ; 6.77\left(\mathrm{~d}, 2 \mathrm{H}\right.$, phenyl, $\left.\mathrm{C}_{3} \mathrm{H}, \mathrm{C}_{5} \mathrm{H}\right) ; 6.65(\mathrm{~m}, 1 \mathrm{H}$, furan- $\mathrm{H} \beta) .{ }^{13} \mathrm{C}$ NMR (75 MHz, DMSO) $\delta$ ppm: 156.78 (1C, phenyl-C-OH); $152.78(1 \mathrm{C}, \mathrm{C}=\mathrm{N}) ; 145.97(2 \mathrm{C}$, phenyl, $C_{2}$ and $\left.C_{5}\right) 142.75$ (1C, furan-C $\alpha$ ); 122.86 (1C, furan- $\mathrm{C} \gamma$ ); 116.07 (2C, phenyl, $\mathrm{C}_{3}$ and $\mathrm{C}_{5}$ ); $112.82\left(1 \mathrm{C}\right.$, furan-C $\beta$ ). $m / z\left(\mathrm{M}^{+}\right)$: 188.21. Anal. Calcd. for $\mathrm{C}_{11} \mathrm{H}_{9} \mathrm{NO}_{2}: \mathrm{C}, 70.58 ; \mathrm{H}$, 4.85; N, 7.48. Found: $C, 70.36 ; \mathrm{H}, 4.58, \mathrm{~N}, 7.37$. IR: $v\left(\mathrm{CH}=\mathrm{N}\right.$, imine) $1630 \mathrm{~cm}^{-1}$.

(E)-2-(furan-2-ylmethyleneamino)phenol, brown powder as 77\% yield $(4.5 \mathrm{~g}, 24.03 \mathrm{mmol}$ ). m.p. $68-69^{\circ} \mathrm{C}$. $\mathrm{R}_{\mathrm{f}}=0.85$ (silica, $\left.\mathrm{CH}_{2} \mathrm{Cl}_{2} / \mathrm{MeOH}, 9 / 1\right)^{1} \mathrm{H} \mathrm{NMR}\left(300 \mathrm{MHz}, \mathrm{CDCl}_{3}\right) \delta \mathrm{ppm}$ : $8.49(\mathrm{~s}, 1 \mathrm{H}, \mathrm{CH}=\mathrm{N}) ; 7.63(\mathrm{~d}, 1 \mathrm{H}$, furan- $\mathrm{H} \alpha) ; 7.25(\mathrm{~d}, 1 \mathrm{H}$, furan- $\mathrm{H} \gamma) ; 7.17\left(\mathrm{t}\right.$, phenyl, $\left.\mathrm{C}_{4} \mathrm{H}\right) ; 7.07$ (s, phenyl, $\left.\mathrm{C}_{3} \mathrm{H}\right) ; 7.01\left(\mathrm{~d}, 1 \mathrm{H}\right.$, phenyl, $\left.\mathrm{C}_{6} \mathrm{H}\right) ; 6.88\left(\mathrm{t}\right.$, phenyl, $\left.\mathrm{C}_{5} \mathrm{H}\right) ; 5.26(\mathrm{~m}, 1 \mathrm{H}$, furan- $\mathrm{H} \beta)$. ${ }^{13} \mathrm{C}$ NMR $\left(75 \mathrm{MHz}, \mathrm{CDCl}_{3}\right) \delta$ ppm: $146.09(1 \mathrm{C}, \mathrm{CH}=\mathrm{N}) ; 144.74$ (1C, furan-C $\left.\alpha\right) ; 129.01(1 \mathrm{C}$, furan- $\mathrm{C} \gamma$ ); 120.10 (1C, phenyl- $\left.\mathrm{C}_{4}\right) ; 116.54$ (1C, phenyl, $\left.\mathrm{C}_{3}\right) ; 115.75$ (1C, phenyl- $\left.\mathrm{C}_{6}\right) ; 115.27$ (1C, phenyl-C5); 110.17 (1C, furan-C $\beta$ ). $m / z\left(\mathrm{M}^{+}\right)$: 188.04. Anal. Calcd. for $\mathrm{C}_{11} \mathrm{H}_{9} \mathrm{NO}_{2}$ : $\mathrm{C}$, 70.58; H, 4.85; N, 7.48. Found: C, 70.42; H, 4.63, N, 7, 21. IR: $v\left(\mathrm{CH}=\mathrm{N}\right.$, imine) $1605 \mathrm{~cm}^{-1}$.

b-Preparation of 3-Glycidoxypropyl-functionalized Silica (Si-Ep)

Si-EP was synthesized according to our published procedure [52,53]. 
c-Fabrication of Schiff Base-Substituted Silica: Ortho-Schiff Base Silica (Si-o-OR) and Para-Schiff Base Silica (Si-p-OR)

The hydroxy-Schiff base ligands (E)-4-(furan-2-ylmethyleneamino) phenol or (E)-2(furan-2-ylmethyleneamino) phenol were firstly transformed into the alcoolate derivatives by applying sodium metal in THF. The suspension of 3-glycidoxypropyl-functionalized silica Si-EP (1 g) in $30 \mathrm{~mL}$ of DMF was added, and the mixture was heated to reflux under continuous stirring for $24 \mathrm{~h}$. The solids Si-o-OR and Si-p-OR were filtered and washed by Soxhlet extraction with organic solvents for $12 \mathrm{~h}$.

\subsubsection{Characterization}

Elemental analyses were performed by the Microanalysis Centre Service (CNRS). FT-IR spectra were obtained using a Perkin Elmer System 2000. SEM images were obtained on a FEI-Quanta 200. Mass loss determinations were performed in a 90:10 $\mathrm{O}_{2(\mathrm{~g})} / \mathrm{N}_{2(\mathrm{~g})}$ atmosphere on a Perkin Elmer Diamond TG/DTA, at a heating rate of $10^{\circ} \mathrm{C} \mathrm{min}{ }^{-1}$. The specific area of modified silica was determined using the BET equation. Nitrogen adsorptiondesorption was obtained by means of a Thermoquest Sorpsomatic 1990 analyzer after the material had been purged in a stream of dry $\mathrm{N}_{2(\mathrm{~g})}$.

\subsubsection{Batch Adsorption Experiments}

The batch method was used in order to examine the sorption performances of $\mathrm{Cu}(\mathrm{II})$ on the modified materials Si-o-OR and Si-p-OR. For all experiments, we set the mass of adsorbent at $10 \mathrm{mg}$ and the volume of the metal solution at $10 \mathrm{~mL}$. Optimum parameters of $\mathrm{pH}$, contact time, initial concentration and temperature were determined as follows:

- $\quad$ The $\mathrm{pH}$ value ranged from 1-7 after adjusting with dilute hydrochloric acid and sodium hydroxide solution. The uptake capacity of $\mathrm{Cu}(\mathrm{II})$ increased to a maximum value found at $\mathrm{pH}=6$;

- $\quad$ The effect of contact time was checked for 5-35 min. The equilibrium was reached after 25 min;

- The optimum concentration was determined by varying the initial concentration (from 10 to $300 \mathrm{mg} \mathrm{L}^{-1}$ ). The studies reveal that the uptake of copper ions onto both adsorbents is maximum within the following optimum conditions: $\mathrm{m}=10 \mathrm{mg}$ of adsorbent, $\mathrm{V}=10 \mathrm{~mL}$ of copper ion solution, $\mathrm{t}=25 \mathrm{~min}, \mathrm{pH}=6$ and $[\mathrm{Cu}(\mathrm{II})]=120 \mathrm{mg}$ $\mathrm{L}^{-1}$ at $25^{\circ} \mathrm{C}$.;

- $\quad$ The effect of temperature was investigated over the range 25 to $45^{\circ} \mathrm{C}$.

After extraction, the solid phase was separated by filtration using a $0.45 \mu \mathrm{m}$ nylon membrane. The residual copper concentration of the supernatant was determined by FAAS. Analyses were performed twice, and the mean data are reported. The adsorption capacity $\left(\mathrm{q}_{\mathrm{e}}, \mathrm{mg} \mathrm{g}^{-1}\right)$ of adsorbents was evaluated by the following equation [54]:

$$
\mathrm{q}_{\mathrm{e}}=\left(\mathrm{C}_{0}-\mathrm{C}_{\mathrm{e}}\right) \times \mathrm{V} / \mathrm{W}
$$

In this formula, $\mathrm{C}_{0}\left(\mathrm{mg} \mathrm{L}^{-1}\right)$ and $\mathrm{C}_{\mathrm{e}}\left(\mathrm{mg} \mathrm{L}^{-1}\right)$ refer to the initial and equilibrium $\mathrm{Cu}$ (II) concentrations respectively; $\mathrm{V}(\mathrm{mL})$ is the solution volume, and $\mathrm{W}(\mathrm{g})$ is the adsorbent mass.

\subsection{Theoretical Study}

The geometry optimizations of the Schiff bases and $\mathrm{Cu}$ complexes ( $\mathbf{C u} @ S i-o-O R$ and Cu@Si-p-OR) were carried out with DFT(B3LYP) level of theory using the basis set $6-311 \mathrm{G}++(\mathrm{d}, \mathrm{p})$ for $\mathrm{H}, \mathrm{C}, \mathrm{N}$, and $\mathrm{O}$ atoms and LANL2DZ for the $\mathrm{Cu}$ atom $[55,56]$. Nucleophilic Parr functions (P-) of the two studied Schiff bases were obtained from the Mulliken atomic spin density (MASD). DFT, MASD and NBO calculations were performed using the GAUSSIAN 09 package [57]. Besides, NBO analysis allows the study of the role of intermolecular orbital interaction in the complex, particularly the prediction of the change in Gibbs free energies of complexation energy $\left(\Delta G_{C}\right)$ and binding energy related to the 
length that assures coordination between the ligand and $\mathrm{Cu}(\mathrm{II})$ ion. The $\Delta \mathrm{G}_{\mathrm{C}}$ is calculated at $298.15 \mathrm{~K}$ and $1 \mathrm{~atm}$ by the following formula [53]:

$$
\Delta \mathrm{G}_{\mathrm{C}}=\mathrm{G}_{\text {complex }}-\left(\mathrm{G}_{\mathrm{Cu}(\mathrm{II})}+\mathrm{G}_{\text {Schiff base }}\right)
$$

where $G_{\text {complex }}, G_{\mathrm{Cu}(\mathrm{II})}$, and $\mathrm{G}_{\text {schiff base }}$ are the free energies of the complex, the $\mathrm{Cu}(\mathrm{II})$, and the Schiff bases (Si-p-OR and Si-o-OR), respectively.

The intramolecular interactions of Si-o-OR and Si-p-OR were qualitatively evaluated in terms of NBI analysis using the multiwfn software and VMD for visualization. This approach is based on the relationship between the electron density $\rho(r)$ and the reduced density gradient $s$, which is given as follows:

$$
s=\left(1 / 2\left(3 \pi^{2}\right)^{1 / 3}\right) \cdot\left(|\Delta \rho| / \rho^{4 / 3}\right)
$$

This allows isosurfaces of $s$ to be given at low densities, and thus allows for the visualization of the position and nature of non-binding interactions in the 3D space (either repulsive, Van der Waals, attractive or all).

Quantum theory of atoms in molecules (QTAIM) analysis using the Multiwfn software was performed in this study to obtain a greater understanding of local reactivity related to the atoms of Si-p-OR and Si-o-OR and of the kind of interaction which occurs when these ligands interact with $\mathrm{Cu}$ (II) (non-covalent or covalent or both) [15].

\section{Conclusions}

In summary, this study reports the preparation of two new hybrid materials, Si-o-OR and Si-p-OR, designed for the adsorption of $\mathrm{Cu}$ (II) ions. According to our adsorption study, the optimum $\mathrm{pH}$ for high uptake capacity is found at $\mathrm{pH}=6$, which favours applications under neutral conditions. The saturation of the active sites of the adsorbents is rapid and does not exceed $25 \mathrm{~min}$, which is largely consistent with the pseudo-second order model that describes the adsorption kinetics of $\mathrm{Cu}$ (II) on the two adsorbents. Additionally, the homogeneity of the adsorption was indicated by the Langmuir model. Our thermodynamic study shows that the adsorption of copper becomes more favourable with increasing temperature, which means that the adsorption reaction is favourable. Most interestingly, Si-o-OR and Si-p-OR exhibit remarkable selectivity towards $\mathrm{Cu}(\mathrm{II})$ in the presence of different ions. Following our adsorption mechanism and computational studies, Si-o-OR can be considered as a promising material to remove copper ions from aquatic media.

Author Contributions: S.T. and S.R.: conceptualization, supervision, project administration, methodology, resources, data curation, writing-original draft, review and editing; Z.L.: elaboration of theoretical aspects, data curation, writing — original draft, review and editing; R.S. and O.R.: experimental conduction; Y.G.: characterization, supervision, project administration, review and editing, methodology; Z.M.A. and Y.N.M.: project administration, methodology, writing—original draft and paying of publication fees. All authors have read and agreed to the published version of the manuscript.

Funding: This research received no external funding.

Institutional Review Board Statement: Not applicable.

Informed Consent Statement: Not applicable.

Acknowledgments: This work was supported by Wallonie Bruxelles International (WBI COP22 Morocco), CNRST (ESRFC-CNRST-P10) and FNRS (CDR 33694457, PDR T.0095.21). The authors extend their appreciation to the Deanship of Scientific Research at King Khalid University for funding this work through a research group project under grant number (R.G.P. 2/26/42).

Conflicts of Interest: All authors declared that there are no conflict of interest.

Sample Availability: Not available. 


\section{References}

1. Piccolo, A.; de Martino, A.; Scognamiglio, F.; Ricci, R.; Spaccini, R. Efficient simultaneous removal of heavy metals and polychlorobiphenyls from a polluted industrial site by washing the soil with natural humic surfactants. Environ. Sci. Pollut. Res. 2021, 28, 25748-25757. [CrossRef]

2. Awual, M.R. New type mesoporous conjugate material for selective optical copper (II) ions monitoring \& removal from pol-luted waters. Chem. Eng. J. 2017, 307, 85-94.

3. Esmieu, C.; Guettas, D.; Conte-Daban, A.; Sabater, L.; Faller, P.; Hureau, C. Copper-targeting approaches in Alzheimer's dis-ease: How to improve the fallouts obtained from in vitro studies. Inorg. Chem. 2019, 58, 13509-13527. [CrossRef]

4. Chen, L.; Tu, Q.; Yang, X.; Hu, X.; Sun, X.; Li, H. MgAl layered double hydroxides intercalated with edta: Cu(II) recovery and mechanism. ChemistrySelect 2020, 5, 11299-11304. [CrossRef]

5. Nystroem, F.; Nordqvist, K.; Herrmann, I.; Hedstroem, A.; Viklander, M. Removal of metals and hydrocarbons from storm-water using coagulation and flocculation. Water Res. 2020, 182, 115919. [CrossRef] [PubMed]

6. $\quad$ Muruchi, L.; Schaeffer, N.; Passos, H.; Mendonça, C.M.N.; Coutinho, J.A.P.; Jimenez, Y.P. Sustainable extraction and separation of rhenium and molybdenum from model copper mining effluents using a polymeric aqueous two-phase system. ACS Sustain. Chem. Eng. 2019, 7, 1778-1785. [CrossRef]

7. Zereshki, S.; Shokri, A.; Karimi, A. Application of a green emulsion liquid membrane for removing copper from contaminated aqueous solution: Extraction, stability, and breakage study using response surface methodology. J. Mol. Liq. 2021, $325,115251$. [CrossRef]

8. Song, G.; Fu, Q.; Pan, C. Copper-graphene composite foils via electro-deposition: A mini review. MRS Adv. 2018, 3, 37-44. [CrossRef]

9. Drenkova-Tuhtan, A.; Sheeleigh, E.K.; Rott, E.; Meyer, C.; Sedlak, D.L. Sorption of recalcitrant phosphonates in reverse osmosis concentrates and wastewater effluents-influence of metal ions. Water Sci. Technol. 2021, 83, 934-947. [CrossRef] [PubMed]

10. Leus, K.; Folens, K.; Nicomel, N.R.; Perez, J.P.H.; Filippousi, M.; Meledina, M.; Dîrtu, M.M.; Turner, S.; van Tendeloo, G.; Garcia, Y.; et al. Removal of arsenic and mercury species from water by covalent triazine dramework en-capsulated gamma-Fe $\mathrm{O}_{3}$ nanoparticles. J. Hazard. Mater. 2018, 353, 312-319. [CrossRef] [PubMed]

11. Feizi, M.; Jalali, M. Leaching of Cd, Cu, Ni and $\mathrm{Zn}$ in a sewage sludge-amended soil in presence of geo- and nano-materials. J. Clean. Prod. 2021, 297, 126506. [CrossRef]

12. Zhou, T.; Cheng, X.; Pan, Y.; Li, C.; Gong, L.; Zhang, H. Mechanical performance and thermal stability of glass fibre reinforced silica aerogel composites based on co-precursor method by freeze drying. Appl. Surf. Sci. 2018, 437, 321-328. [CrossRef]

13. Bonab, S.A.; Moghaddas, J.; Rezaei, M. In-situ synthesis of silica aerogel/polyurethane inorganic-organic hybrid nanocomposite foams: Characterization, cell microstructure and mechanical properties. Polymer 2019, 172, 27-40. [CrossRef]

14. Pawlaczyk, M.; Schroeder, G. Adsorption studies of Cu(II) ions on dendrimer-grafted silica-based materials. J. Mol. Liq. 2019, 281, 176-185. [CrossRef]

15. Tighadouini, S.; Radi, S.; Massaoudi, M.; Lakbaibi, Z.; Ferbinteanu, M.; Garcia, Y. Efficient and environmentally friendly adsorbent based on $\beta$ ketoenol-pyrazole-thiophene for heavy-metal ion removal from aquatic medium: A combined experi-mental and theoretical study. ACS Omega 2020, 5, 17324-17336. [CrossRef]

16. Tighadouini, S.; Radi, S.; Anannaz, M.; Bacquet, M.; Degoutin, S.; Tillard, M.; Eddike, D.; Amhamdi, H.; Garcia, Y. Engineering $\beta$-ketoenol structure functionality in hybrid silica as excellent adsorbent material for removal of heavy metals from water. New $\mathrm{J}$. Chem. 2018, 42, 13229-13240. [CrossRef]

17. Tighadouini, S.; Radi, S.; Elidrissi, A.; Zaghrioui, M.; Garcia, Y. Selective confinement of CdII in silica particles functionalized with $\beta$-keto-enol-bisfuran receptor: Isotherms, kinetic and thermodynamic studies. Eur. J. Inorg. Chem. 2019, 2019, 3180-3186. [CrossRef]

18. Tighadouini, S.; Radi, S.; Elidrissi, A.; Haboubi, K.; Bacquet, M.; Degoutin, S.; Zaghrioui, M.; Garcia, Y. Removal of toxic heavy metals from river water samples using a porous silica surface modified with a new $\beta$-ketoenolic host. Beilstein J. Nanotechnol. 2019, 10, 262-273. [CrossRef] [PubMed]

19. Tighadouini, S.; Radi, S.; Ferbinteanu, M.; Garcia, Y. Highly selective removal of $\mathrm{Pb}(\mathrm{II})$ by a pyridylpyrazole- $\beta$-ketoenol recep-tor covalently bonded onto the silica surface. ACS Omega 2019, 4, 3954-3964. [CrossRef]

20. Aggoun, D.; Fernández-García, M.; López, D.; Bouzerafa, B.; Ouennoughi, Y.; Setifi, F.; Ourari, A. New nickel (II) and copper (II) bidentate Schiff base complexes, derived from dihalogenated salicylaldehyde and alkylamine: Synthesis, spectroscopic, thermogravimetry, crystallographic determination and electrochemical studies. Polyhedron 2020, 187, 114640. [CrossRef]

21. Mudi, P.K.; Bandopadhyay, N.; Joshi, M.; Shit, M.; Paul, S.; Choudhury, A.R.; Biswas, B. Schiff base triggering synthesis of copper(II) complex and its catalytic fate towards mimics of phenoxazinone synthase activity. Inorg. Chim. Acta 2020, 505, 119468. [CrossRef]

22. Jiang, S.; Ni, H.; Liu, F.; Gu, S.; Yu, P.; Gou, Y. Binuclear Schiff base copper(II) complexes: Syntheses, crystal structures, HSA interaction and anticancer properties. Inorg. Chim. Acta 2020, 499, 119186. [CrossRef]

23. Zhang, Y.; Cao, X.; Wu, G.; Wang, J.; Zhang, T. Quaternized salicylaldehyde Schiff base modified mesoporous silica for efficiently sensing $\mathrm{Cu}(\mathrm{II})$ ions and their removal from aqueous solution. Appl. Surf. Sci. 2020, 527, 146803. [CrossRef] 
24. Betihaa, M.A.; Moustafaa, Y.M.; Betihaa, M.A.; Moustafaa, Y.M.; El-Shahatc, M.F.; Rafikc, E. Polyvinylpyrroli-done-AminopropylSBA-15 Schiff Base hybrid for efficient removal of divalent heavy metal cations from wastewater. J. Hazard. Mater. 2020, 397, 122675. [CrossRef] [PubMed]

25. Wangab, W.; Tao, G.W.; Yin, Z.; Yuan, Y.; Zhang, Y. Synthesis of thiazole Schiff base modified SBA-15 mesoporous silica for se-lective $\mathrm{Pb}$ (II) adsorption. J. Taiwan Inst. Chem. Eng. 2021, 125, 349-359. [CrossRef]

26. Zhao, J.; Luan, L.; Li, Z.; Duan, Z.; Li, Y.; Zheng, S.; Xue, Z.; Xu, W.; Niu, Y. The adsorption property and mechanism for Hg(II) and $\mathrm{Ag}(\mathrm{I})$ by Schiff base functionalized magnetic Fe3O4 from aqueous solution. J. Alloy. Compd. 2020, 825, 154041. [CrossRef]

27. Janeta, M.; Lis, T.; Szafert, S. Zinc imine polyhedral oligomeric silsesquioxane as a quattro-site catalyst for the synthesis of cyclic carbonates from epoxides and low-pressure $\mathrm{CO}_{2}$. Chem.-A Eur. J. 2020, 26, 13686-13697. [CrossRef]

28. Di Iulio, C.; Jones, M.D.; Mary Mahon, F.; Apperley, D.C. Zinc(II) silsesquioxane complexes and their application for the ring-opening polymerization of rac-lactide. Inorg. Chem. 2010, 49, 10232-10234. [CrossRef]

29. Sing, K.S.W.; Everett, D.H.; Haul, R.A.W.; Moscou, L.; Pierotti, R.A.; Rouquerol, J.; Siemieniewska, T. Reporting physisorption data for gas/solid systems with special reference to the determination of surface area and porosity (IUPAC Recommendations 1984). Pure Appl. Chem. 1985, 57, 603-619. [CrossRef]

30. Yu, Z.; Dang, Q.; Liu, C.; Cha, D.; Zhang, H.; Zhu, W.; Zhang, Q.; Fan, B. Preparation and characterization of poly(maleic ac-id)-grafted cross-linked chitosan microspheres for Cd(II) adsorption. Carbohydr. Polym. 2017, 172, 28-39. [CrossRef]

31. Largitte, L.; Pasquier, R. A review of the kinetics adsorption models and their application to the adsorption of lead by an acti-vated carbon. Chem. Eng. Res. Des. 2016, 109, 495-504. [CrossRef]

32. Limousin, G.; Gaudet, J.-P.; Charlet, L.; Szenknect, S.; Barthès, V.; Krimissa, M. Sorption isotherms: A review on physical bases, modeling and measurement. Appl. Geochem. 2007, 22, 249-275. [CrossRef]

33. Fu, Y.; Jiang, J.; Chen, Z.; Ying, S.; Wang, J.; Hu, J. Rapid and selective removal of $\mathrm{Hg}(\mathrm{II})$ ions and high catalytic performance of the spent adsorbent based on functionalized mesoporous silica/poly(m-aminothiophenol) nanocomposite. J. Mol. Liq. 2019, 286, 110746. [CrossRef]

34. Chen, X. Modeling of experimental adsorption isotherm data. Information 2015, 6, 14-22. [CrossRef]

35. Krishni, R.; Foo, K.Y.; Hameed, B. Adsorption of methylene blue onto papaya leaves: Comparison of linear and nonlinear isotherm analysis. Desalin. Water Treat. 2013, 52, 6712-6719. [CrossRef]

36. Li, Z.; Xiao, D.; Ge, Y.; Koehler, S. Surface-functionalized porous lignin for fast and efficient lead removal from aqueous solution. ACS Appl. Mater. Interfaces 2015, 7, 15000-15009. [CrossRef]

37. Milonjic, S. A consideration of the correct calculation of thermodynamic parameters of adsorption. J. Serbian Chem. Soc. 2007, 72, 1363-1367. [CrossRef]

38. Thue, P.S.; Sophia, A.C.; Lima, E.C.; Wamba, A.G.; de Alencar, W.S.; Reis, G.; Rodembusch, F.; Dias, S. Synthesis and characterization of a novel organic-inorganic hybrid clay adsorbent for the removal of acid red 1 and acid green 25 from aqueous solutions. J. Clean. Prod. 2018, 171, 30-44. [CrossRef]

39. Gao, B.; Gao, Y.; Li, Y. Preparation and chelation adsorption property of composite chelating material poly $($ amidoxime $) / \mathrm{SiO}_{2}$ toward heavy metal ions. Chem. Eng. J. 2010, 158, 542-549. [CrossRef]

40. Radi, S.; El Abiad, C.; Moura, N.M.M.; Faustino, M.A.F.; Neves, M.G.P.M.S. New hybrid adsorbent based on porphyrin functionalized silica for heavy metals removal: Synthesis, characterization, isotherms, kinetics and thermodynamics studies. $J$. Hazard. Mater. 2019, 370, 80-90. [CrossRef]

41. Zhang, Y.; Cao, X.; Sun, J.; Wu, G.; Wang, J.; Zhang, D. Synthesis of pyridyl Schiff base functionalized SBA-15 mesoporous silica for the removal of $\mathrm{Cu}(\mathrm{II})$ and $\mathrm{Pb}$ (II) from aqueous solution. J. Sol-Gel Sci. Technol. 2020, 94, 658-670. [CrossRef]

42. Mohammadnezhad, G.; Moshiri, P.; Dinari, M.; Steiniger, F. In situ synthesis of nanocomposite materials based on modi-fiedmesoporous silica MCM-41 and methyl methacrylate for copper (II) adsorption from aqueous solution. J. Iran. Chem. Soc. 2019, 16, 1491-1500. [CrossRef]

43. He, S.; Zhao, C.; Yao, P.; Yang, S. Chemical modification of silica gel with multidentate ligands for heavy metals removal. Desalin. Water Treat. 2014, 57, 1-11. [CrossRef]

44. He, Q.; Chang, X.; Huang, X.; Hu, Z. Determination of trace elements in food samples by ICP-AES after preconcentration with p-toluenesulfonylamide immobilized on silica gel and nanometer $\mathrm{SiO}_{2}$. Microchim. Acta. 2008, 160, 147-152. [CrossRef]

45. Moftakhar, M.K.; Dousti, Z.; Yaftian, M.R.; Ghorbanloo, M. Investigation of heavy metal ions adsorption behavior of silicasupported Schiff base ligands. Desalin. Water Treat. 2016, 57, 27396-27408. [CrossRef]

46. Radi, S.; Tighadouini, S.; El Massaoudi, M.; Bacquet, M.; Degoutin, S.; Revel, B.; Mabkhot, Y.N. Thermodynamics and kinetics of heavy metals adsorption on silica particles chemically modified by conjugated $\beta$-ketoenol furan. J. Chem. Eng. Data 2015, 60, 2915-2925. [CrossRef]

47. Dong, C.; Fu, R.; Sun, C.; Qu, R.; Ji, C.; Niu, Y.; Zhang, Y. Comparison studies of adsorption properties for copper ions in fuel ethanol and aqueous solution using silica-gel functionalized with 3-amino-1,2-propanediol. Fuel 2018, 226, 331-337. [CrossRef]

48. Morcali, M.H.; Zeytuncu, B.; Baysal, A.; Akman, S.; Yucel, O. Adsorption of copper and zinc from sulfate media on a commercial sorbent. J. Environ. Chem. Eng. 2014, 2, 1655-1662. [CrossRef]

49. Radi, S.; El Massaoudi, M.; Bacquet, M.; Degoutin, S.; Adarsh, N.N.; Robeyns, K.; Garcia, Y. A novel environment-friendly hybrid material based on a modified silica gel with a bispyrazole derivative for the removal of $\mathrm{ZnII}, \mathrm{PbII}$, CdIIand CuIItraces from aqueous solutions. Inorg. Chem. Front. 2017, 4, 1821-1831. [CrossRef] 
50. Radi, S.; Tighadouini, S.; Feron, O.; Riant, O.; Mabkhot, Y.N.; Al-Showiman, S.S.; Ben Hadda, T.; El-Youbi, M.; Benabbes, R.; Saala-oui, E. One pot synthesis, antiturmor, antibacterial and antifingal activities of some Schiff base heterocycles. Int. J. Pharm. 2015, 5, 39-45.

51. Tighadouni, S.; Radi, S.; Sirajuddin, M.; Akkurt, M.; Özdemir, N.; Ahmad, M.; Mabkhot, Y.N.; Ben Hadda, T. In vitro antifungal, anticancer activities and POM analyses of a novel bioactive schiff base 4-\{[(e)-furan-2-ylmethylidene]amino\}phenol: Synthesis, characterization and crystal structure. J. Chem. Soc. Pak. 2016, 38, 157-165.

52. Radi, S.; Toubi, Y.; El-Massaoudi, M.; Bacquet, M.; Degoutin, S.; Mabkhot, Y. Efficient extraction of heavy metals from aqueous solution by novel hybrid material based on silica particles bearing new Schiff base receptor. J. Mol. Liq. 2016, 223, 112-118. [CrossRef]

53. Radi, S.; Attayibat, A.; El-Massaoudi, M.; Bacquet, M.; Jodeh, S.; Warad, I.; Al-Showiman, S.; Mabkhot, Y.N. C,N-bipyrazole re-ceptor grafted onto a porous silica surface as a novel adsorbent based polymer hybrid. Talanta 2015, 143, 1-6. [CrossRef]

54. Xue, X.; Li, F. Removal of $\mathrm{Cu}(\mathrm{II})$ from aqueous solution by adsorption onto functionalized SBA-16 mesoporous silica. Microporous Mesoporous Mater. 2008, 116, 116-122. [CrossRef]

55. Ma, H.; Chen, S.; Liu, Z.; Sun, Y. Theoretical elucidation on the inhibition mechanism of pyridine-pyrazole compound: A hartreefock study. J. Mol. Struct. 2006, 774, 19-22. [CrossRef]

56. Jamalizadeh, E.; Hosseini, S.; Jafari, A. Quantum chemical studies on corrosion inhibition of some lactones on mild steel in acid media. Corros. Sci. 2009, 51, 1428-1435. [CrossRef]

57. Dutta, A.; Saha, S.K.; Banerjee, P.; Sukul, D. Correlating electronic structure with corrosion inhibition potentiality of some bis-benzimidazole derivatives for mild steel in hydrochloric acid: Combined experimental and theoretical studies. Corros. Sci. 2015, 98, 541-550. [CrossRef] 